\author{
塩害環境下における $\mathrm{RC}$ 柱の鉄筋腐食ひび割れ挙動 \\ および横補強筋のひずみ上昇 \\ CRACKING BEHAVIOR CAUSED BY CORROSION AND INCREASING STRAIN OF \\ TRANSVERSE BARS IN RC COLUMNS UNDER A SALT-ATTACK ENVIRONMENT
}

\author{
篠原保二*, 覚張 雄一郎**, 丸山裕生 ${ }^{* * *}$, 南 正 樹****, 宮内博之***** \\ Yasuji SHINOHARA, Yuichiro GAKUHARI, Hiroki MARUYAMA, \\ Jeongsoo NAM and Hiroyuki MIYAUCHI
}

\begin{abstract}
Accelerated corrosion tests were performed on ten specimens which are designed as elements cut from RC columns in order to investigate cracking behaviors and increasing strains of bars due to chloride attack. The variable factors are concrete strength, longitudinal and transverse bar arrangement, and covering depth. Test results indicated that a corrosion cracking is most early appeared on the surface above transverse bars of the specimens having lower concrete strength and thinner cover, and that corrosion cracking behaviors greatly depend on concrete strength, namely, pore structures in the cement paste. An ultrasonic inspection can early detect damage around corroding bars.
\end{abstract}

Keywords Chloride attack, Corroded steel bar, Cracking behavior, Increasing strain, Ultrasonic inspection 塩害, 腐食鉄筋, ひび割れ挙動, ひずみ上昇, 超音波探査

\section{1. はじめに}

仕様設計から性能設計への移行に伴い，鉄筋コンクリート（以下 $\mathrm{RC}$ と略す) 造建物の設計においても, 安全性能に関連する最大耐力 の把握だけでなく, その後の継続使用に対する使用性能および経年 劣化に伴う耐久性能に関しても定量的に評価 ${ }^{1)}$ 寸ることが必要にな ってきている。 $\mathrm{RC}$ 造建物の高経年化が進行していくなかで, 劣化現 象が建物の使用性や耐久性に及ぼす影響を明らかにすることは，健 全性評価や補修・補強方法の開発および環境問題の観点から, 重要 な課題となっていくと思われる。

塩害による鉄筋腐食は RC 造建物の性能劣化の主な要因の一つで ある。海洋から飛来する塩化物イオンがかぶりコンクリートを浸透 し, 内部の鉄筋表面に到達し, 鉄筋の不導体被膜が破壊されると腐 食が始まる。鉄筋腐食は鉄筋の健全な断面が欠損するのみならず, 鉄との体積比で $2 \sim 6$ 倍 に膨張する腐食生成物 ${ }^{2}$ によって, 腐食鉄 筋まわりのコンクリートに膨張圧が作用し，鉄筋円周方向には引張 応力 (リングテンション) が発生する。この引張応力がコンクリー 卜の引張強度を上回ると，腐食鉄筋を中心とする放射状の腐食膨張 ひび割れが発生する。 RC 造の柱・梁部材において腐食ひび割れ進展 が，かぶりコンクリートの表面に到達すると，かぶりコンクリート
の一体性が損なわれ，剥落を容易に起こす危険な状態となる。また 主筋の腐食ひび割れが横補強筋を横断する際，横補強筋の引張ひず みが上昇し，見かけの降伏強度が低下寸ることも，実験および解析 3),4)によって確認されている。

鉄筋腐食が RC 造建物の健全性におよぼす影響を評価する場合, コンクリート内部の鉄筋の腐食量を把握する必要があるが，コンク リート表面の腐食ひび割れ幅から内部鉄筋の腐食量を推定すること が可能であれば，最も現実的で簡便な推定方法と思われる。このた め，内部鉄筋の腐食量と表面ひび割れ幅の関係を明らかにするため に，多くの電気化学的な促進腐食試験が行われている。例えば, Andrade ら ${ }^{5)}$ は断面 $150 \times 150 \mathrm{~mm}$ ，長さ $380 \mathrm{~mm}$ のコンクリート試験 体（W/C=0.5）に，かぶり厚さの異なる単筋（径 $16 \mathrm{~mm} ）$ を配し，促 進腐食実験を行っている。また, 橘高ら の゙一辺 $100 \mathrm{~mm}$ のコンクリ 一下立方体（W/C $=0.4 ， 0.5 ， 0.6 ）$ に単筋（D10，D13，D16）をかぶ り厚さ $10 ， 20 ， 30 \mathrm{~mm}$ に設定して埋め込んだ試験体を用いて促進腐 食試験を行い，表面ひび割れ発生時 $(0.1 \mathrm{~mm})$ の鉄筋腐食減量の推

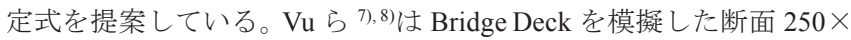
$700 \mathrm{~mm}$, 長さ $1000 \mathrm{~mm}$ のコンクリート $(\mathrm{W} / \mathrm{C}=0.45,0.5,0.58)$ に, 径 $16 \mathrm{~mm}$ の鉄筋を 5 本, $150 \mathrm{~mm}$ 間隔で配した試験体に対して，促

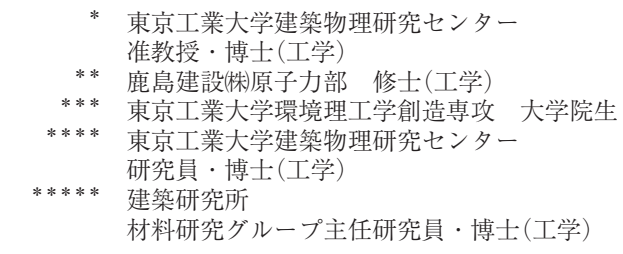

Assoc. Prof., Struct. Eng. Research Center, Tokyo Institute of Technology, Dr.Eng.

Nuclear Power Department, Kajima corporation, Master of Engineering Grad. Stud., Dept. of Environmental Sci. and Tech., Tokyo Institute of Technology Researcher, Structural Engineering Research Center, Tokyo Institute of Technology, Dr.Eng.

Senior Research Engineer, Department of Building Materials and Components, BRI, Dr.Eng. 
進腐食実験を行い, ひび割れの発生・ひび割れ幅を計測している。 かぶり厚さを $25 \mathrm{~mm}$ から $50 \mathrm{~mm}$ に倍増すると, 表面ひび割れの発 生が遅れ, 内部鉄筋の腐食量は大きくなると報告している。また, Kukrit ら ${ }^{9}$ は二次元ひび割れ解析を行い，コンクリート内部の腐食 生成物の挙動を検討している。かぶり厚さが小さい場合, 腐食ひび 割れに侵入する腐食生成物は少なく, 比較的早い段階でコンクリー 卜表面にひび割れが現れ，促進腐食実験結果との整合性が良い。一 方, かぶり厚さが大きい場合, かぶり表面にひび割れが発生するま で時間を要し, 腐食生成物のひび割れ面への侵入 (buffer effect), さ らにクリープを考慮する必要があると指摘している。Aris ら ${ }^{3}$ は, $\mathrm{F}_{\mathrm{c}} 24$ と $\mathrm{F}_{\mathrm{c}} 48$ を使用した $\mathrm{RC}$ 梁試験体の腐食ひび割れ挙動の相違は, コンクリートの細孔構造の相違に起因していると仮定し，簡便に腐 食生成物の膨張倍率を変えることによって, 実験結果と整合性のあ る腐食ひび割れ挙動を平面応力解析によって再現している。セメン トペースト中の空隙が多く, 腐食生成物が空隙に侵入する可能性が 高い $F_{\mathrm{c}} 24$ は膨張倍率を 2.0 と低めに設定し, セメントペースト中の 空隙が少ない $\mathrm{F}_{\mathrm{c}} 48$ に対しては, 2.5 3.0 の膨張倍率を提案している。 しかし, 既往の研究の大多数は単筋をコンクリート試験片に埋め込 んだ試験体 5), 6)または横補強筋の無い試験体 7), 8), 9)を使用しており, 実際の柱・梁部材の配筋を考慮していない。また試験体の鉄筋径や かぶり厚さが実設計におけるものより小さく, 実環境における塩化 物イオン浸透の過程を考慮した研究例は殆どない。

そこで本実験では，実設計における RC 柱を想定し，断面 $600 \times$ $600 \mathrm{~mm}$ にD25～D38 の主筋を配した試験体を計画した。RC 柱は横 補強筋 3 本分（高さ $300 \mathrm{~mm}$ ) でカットオフした要素試験体とし，コ ンクリート強度・主筋径・かぶり厚さおよび横補強筋の配筋を変動 要因とする 10 体の試験体に対して促進腐食実験を行い, コンクリー 卜表面の腐食ひび割れ幅および横補強筋ひずみ挙動について検討を 行った。促進腐食試験に関しては, 主筋と横補強筋のかぶり厚さの 違いによる塩化物イオン侵入量の相違を考慮し, 主筋と横補強筋の それぞれに導入する電流を制御することによって, 塩害を受ける RC 部材の塩化物イオン濃度分布となるように配慮した。さらに促進腐 食試験中に複数回, 試験体側面方向に透過法による超音波探傷検査 を行い, 超音波の伝播振幅および音速の変動に基づいて, 鉄筋腐食 に伴う鉄筋間の内部腐食ひび割れ性状を検討した。

経年劣化した RC 造建物の構造性能が健全時に比較してどの程度 低下したかを評価する場合, コンクリート内部の鉄筋腐食量をはじ めとする材料劣化を定量的に把握する必要がある。本研究では, 計 測が比較的容易なコンクリート表面の腐食ひび割れ幅から， $\mathrm{RC}$ 造 部材内部の鉄筋の腐食量, 内部腐食ひび割れ性状および横補強筋ひ ずみ挙動に関する情報を得ることを目的としている。腐食ひび割れ 幅とコンクリート内部の材料劣化の関係を得ることによって, かぶ りコンクリートの剥落の危険性や横補強筋のひずみ上昇による残存 せん断耐力などを, 腐食ひび割れ幅から評価することが可能になる。

\section{2. 促進腐食実験}

\section{1 試験体諸元}

Table 1 に促進腐食実験に供した RC 柱試験体諸元を示す。共通因 子は, 断面寸法 $(600 \mathrm{~mm} \times 600 \mathrm{~mm})$ とカットオフ高さ $(300 \mathrm{~mm})$ とし, 横補強筋量と主筋量は全試験体とも同等となるように配筋した。試
Table 1 List of test specimens

\begin{tabular}{|c|c|c|c|c|c|c|c|c|}
\hline \multirow[b]{2}{*}{ Specimen } & \multirow{2}{*}{$\begin{array}{c}\text { Comp. } \\
\text { strength } \\
\left(\mathrm{N} / \mathrm{mm}^{2}\right)\end{array}$} & \multicolumn{3}{|c|}{ Longitudinal bars } & \multicolumn{3}{|c|}{ Transvers bars } & \multirow{2}{*}{$\begin{array}{l}\text { Cover } \\
\text { depth } \\
(\mathrm{mm})\end{array}$} \\
\hline & & $\begin{array}{c}\text { Arrange } \\
\text { ment }\end{array}$ & $\mathrm{p}_{\mathrm{t}}(\%)$ & $p_{g}(\%)$ & $\begin{array}{c}\text { Periph- } \\
\text { eral }\end{array}$ & Core & $\mathrm{p}_{\mathrm{w}}(\%)$ & \\
\hline $12-\mathrm{F}_{\mathrm{c}} 48$ & 44.7 & \multirow{3}{*}{ 12-D32 } & \multirow{3}{*}{0.88} & \multirow{3}{*}{2.65} & \multirow{5}{*}{$\begin{array}{l}\text { D16 } \\
\text { @100 }\end{array}$} & \multirow{5}{*}{-} & \multirow{10}{*}{0.66} & \\
\hline $12-\mathrm{F}_{\mathrm{c}} 72$ & 59.0 & & & & & & & \\
\hline $12-\mathrm{F}_{\mathrm{c}} 24$ & 22.3 & & & & & & & \\
\hline $8-\mathrm{F}_{\mathrm{c}} 48$ & \multirow{3}{*}{44.7} & 8-D38 & 0.95 & 2.53 & & & & 4 \\
\hline $20-\mathrm{F}_{\mathrm{c}} 48$ & & \multirow{4}{*}{$20-\mathrm{D} 25$} & \multirow{4}{*}{0.84} & \multirow{4}{*}{2.82} & & & & \\
\hline $20-\mathrm{T}-\mathrm{F}_{\mathrm{c}} 48$ & & & & & \multirow{3}{*}{$\begin{array}{l}\text { D13 } \\
@ 100\end{array}$} & \multirow{3}{*}{$\begin{array}{l}\text { D10 } \\
@ 100\end{array}$} & & \\
\hline $20-\mathrm{T}-\mathrm{F}_{\mathrm{c}} 72$ & 59.0 & & & & & & & \\
\hline $20-\mathrm{T}-\mathrm{F}_{\mathrm{c}} 24$ & 22.3 & & & & & & & \\
\hline 12-C60 & \multirow{2}{*}{44.7} & \multirow{2}{*}{ 12-D32 } & \multirow{2}{*}{0.88} & \multirow{2}{*}{2.65} & \multirow{2}{*}{$\begin{array}{l}\mathrm{D} 16 \\
\text { (a) } 100\end{array}$} & \multirow{2}{*}{-} & & 60 \\
\hline $12-\mathrm{C} 20$ & & & & & & & & 20 \\
\hline
\end{tabular}

Table 2 Mix proportions

\begin{tabular}{ccccccc}
\hline $\begin{array}{c}\text { Design } \\
\text { strength }\end{array}$ & $\begin{array}{c}\mathrm{W} / \mathrm{C} \\
(\%)\end{array}$ & $\begin{array}{c}\text { Cement } \\
\left(\mathrm{kg} / \mathrm{m}^{3}\right)\end{array}$ & $\begin{array}{c}\text { Water } \\
\left(\mathrm{kg} / \mathrm{m}^{3}\right)\end{array}$ & $\begin{array}{c}\text { Fine } \\
\text { Aggregate } \\
\left(\mathrm{kg} / \mathrm{m}^{3}\right)\end{array}$ & $\begin{array}{c}\text { Coarse } \\
\text { Aggregate } \\
\left(\mathrm{kg} / \mathrm{m}^{3}\right)\end{array}$ & $\begin{array}{c}\text { Admix. } \\
\left(\mathrm{kg} / \mathrm{m}^{3}\right)\end{array}$ \\
\hline $\mathrm{F}_{\mathrm{c}} 24$ & 63.5 & 290 & 184 & 891 & 901 & 2.90 \\
\hline $\mathrm{F}_{\mathrm{c}} 48$ & 43.7 & 389 & 170 & 822 & 923 & 3.89 \\
\hline $\mathrm{F}_{\mathrm{c}} 72$ & 34.1 & 499 & 170 & 804 & 891 & 5.49 \\
\hline
\end{tabular}

Table 3 Mechanical properties of materials

\begin{tabular}{c|ccc|ccccccc}
\hline \multirow{2}{*}{$\begin{array}{c}\text { Mechanical } \\
\text { properties }\end{array}$} & \multicolumn{3}{|c|}{ Concrete } & \multicolumn{6}{c}{ Steel bar } \\
\cline { 2 - 9 } $\begin{array}{c}\text { Comp. strength } \\
\left(\mathrm{N} / \mathrm{mm}^{2}\right)\end{array}$ & 22.3 & 44.7 & 59.0 & - & - & - & - & - & - \\
\hline $\begin{array}{c}\text { Tensile strength } \\
\left(\mathrm{N} / \mathrm{mm}^{2}\right)\end{array}$ & 2.83 & 3.96 & 4.06 & 486 & 493 & 493 & 553 & 611 & 641 \\
\hline $\begin{array}{c}\text { Yield strength } \\
\left(\mathrm{N} / \mathrm{mm}^{2}\right)\end{array}$ & - & - & - & 351 & 349 & 340 & 380 & 439 & 447 \\
\hline $\begin{array}{c}\text { Young's moduli } \\
\left(\times 10^{5} \mathrm{~N} / \mathrm{mm}^{2}\right)\end{array}$ & 0.241 & 0.297 & 0.364 & 1.93 & 1.83 & 1.82 & 1.91 & 1.89 & 1.91 \\
\hline
\end{tabular}

Note: Tensile strength is obtained from a split test.
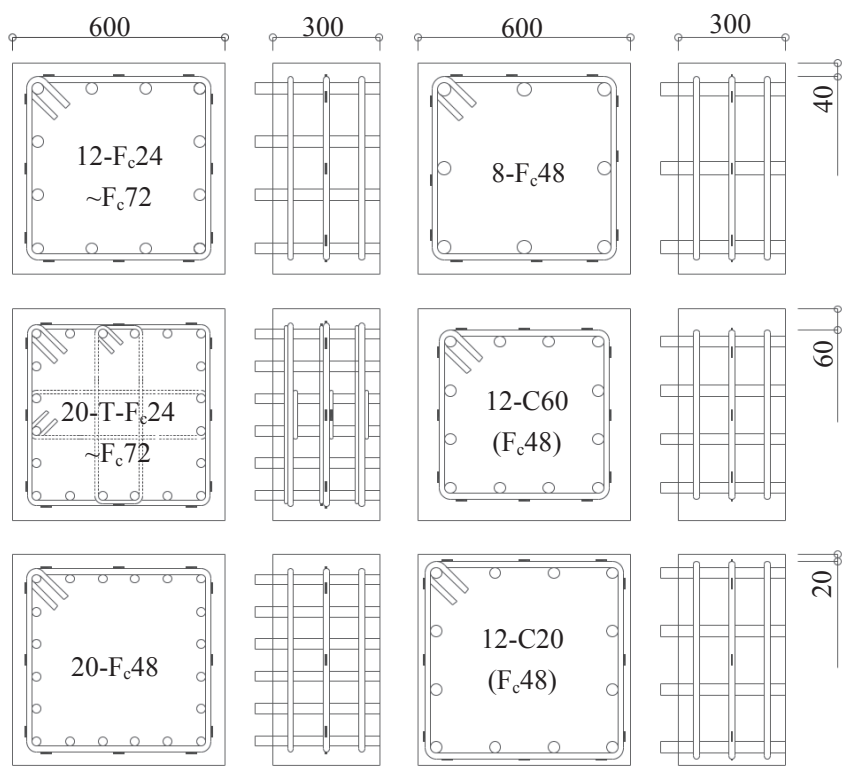

-: Attached strain gages

Fig. 1 Bar arrangements and strain gage positions 
験体に用いたコンクリートの調合を Table 2 に, 使用材料の力学特性 を Table 3 に示す。Fig. 1 に試験体配筋図と横補強筋のひずみゲージ 貼付位置を示寸。ひずみゲージは, 主筋の腐食ひび割れによる横補 強筋のひずみ上昇を検討するため, 中央の横補強筋の四面に 3 枚ず つ貼付した。また, 電食に必要なリード線の接続を容易にするため, 主筋は試験体上面に $50 \mathrm{~mm}$ 突出させた。

変動要因はコンクリート強度・主筋径および本数・かぶり厚・横 補強筋径および形状である。コンクリート調合強度は $\mathrm{F}_{\mathrm{c}} 24, \mathrm{~F}_{\mathrm{c}} 48$, $\mathrm{F}_{\mathrm{c}} 72$ の 3 水準とし, 水セメント比の違いによるセメントペーストの 細孔構造の相違が腐食生成物の拡散・ひび割れ挙動に与える影響 3) を検討する。主筋は 8-D38，12-D32，20-D25 の配筋とし，主筋径お よび主筋間隔の違いによるひび割れ, 横補強筋ひずみ挙動への影響 を検討する。横補強筋は外周補強 D16@100 のみによる配筋および 中子筋を有する D13+D10@100 による配筋の 2 形状とし, 中子筋に よる腐食ひび割れに対する補強効果 ${ }^{3)}$ を検討する。かぶり厚さは 20 $\mathrm{mm}, 40 \mathrm{~mm}, 60 \mathrm{~mm}$ の 3 水準とし, かぶり厚さが腐食生成物の分散 に及ぼす影響9)を検討する。

\section{2 促進腐食試験方法}

Fig. 2 に促進腐食試験の概念図を示寸。試験体は 28 日間の気中養 生後, 側面からのみ塩化物イオンが侵入することを想定して上下面 にエポキシ樹脂コーティングを施した。エポキシ樹脂硬化後， $3 \%$ $\mathrm{NaCl}$ 水溶液に 24 時間浸漬し, 通電による促進腐食試験を開始した。

かぶりコンクリート中の塩化物イオンの移動に関しては, 拡散過 程と考え, 一次元拡散方程式をコンクリート表面の塩化物イオン濃 度を一定 $\mathrm{C}_{0}$ とした解である(1)式が一般によく用いられている ${ }^{10)}$ 。

$$
C(x, t)=C_{0}\left\{1-\operatorname{erf}\left(\frac{x}{2 \sqrt{D_{a p} \cdot t}}\right)\right\}
$$

ここに, $C(x, t)$ は深さ $x(\mathrm{~cm})$, 時間 $t$ (年) における塩化物イオン濃度 $\left(\mathrm{kg} / \mathrm{m}^{3}\right), C_{0}$ は表面の塩化物イオン濃度 $\left(\mathrm{kg} / \mathrm{m}^{3}\right), D_{a p}$ は塩化物イオン の見かけの拡散係数 $\left(\mathrm{cm}^{2} /\right.$ 年) であり, 水セメント比 $W / C$ の 関数で ある(2)式 ${ }^{10)}$ を採用した。さらに, $\operatorname{erf}(s)$ は誤差関数(3)式である。

$$
\begin{aligned}
& \log _{10} D=-3.9(W / C)^{2}+7.2(W / C)-2.5 \\
& \operatorname{erf}(s)=\frac{2}{\sqrt{\pi}} \int_{0}^{s} e^{-\eta^{2}} d \eta
\end{aligned}
$$

主筋と横補強筋とでは, かぶり厚さが異なるため, 実際の $\mathrm{RC}$ 部材 では塩化物イオン濃度も異なっている。腐食ひび割れがコンクリー 卜表面に現れる劣化過程の進展期までは, 内部鉄筋の腐食量が塩化 物イオン濃度に比例するものとして, 主筋と横補強筋の通電時間を 制御できるように, 主筋と横補強筋は個別に並列接続のリード線を 接続し, さらに主筋側のリード線にはスイッチを設置した。主筋と 横補強筋のかぶり厚さにおける塩化物イオン濃度を(1)式によって 評価し, その比率に基づいて主筋の通電を OFF にした。主筋の回路 を遮断した時間割合は, 基準試験体で $50 \%$ 程度, 拡散係数の大きい $\mathrm{F}_{\mathrm{c}} 24$ で $25 \%$ 程度になった。腐食ひび割れ発生後の劣化過程の加速期 に対しては，主筋の通電を ON に保持した。

測定項目は積算電流量・横補強筋ひずみおよび表面ひび割れ幅で ある。積算電流量に関しては, 促進腐食中の各鉄筋の腐食量は積算

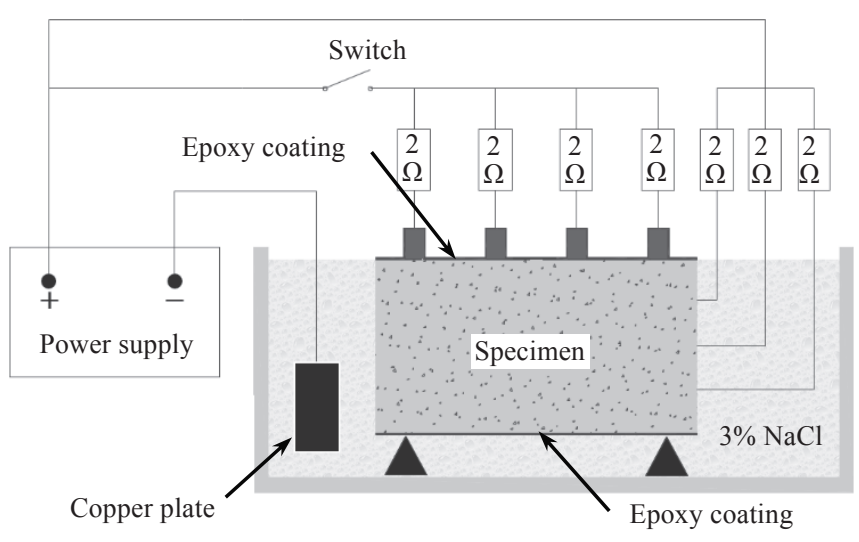

Fig. 2 Overview of accelerated corrosion test
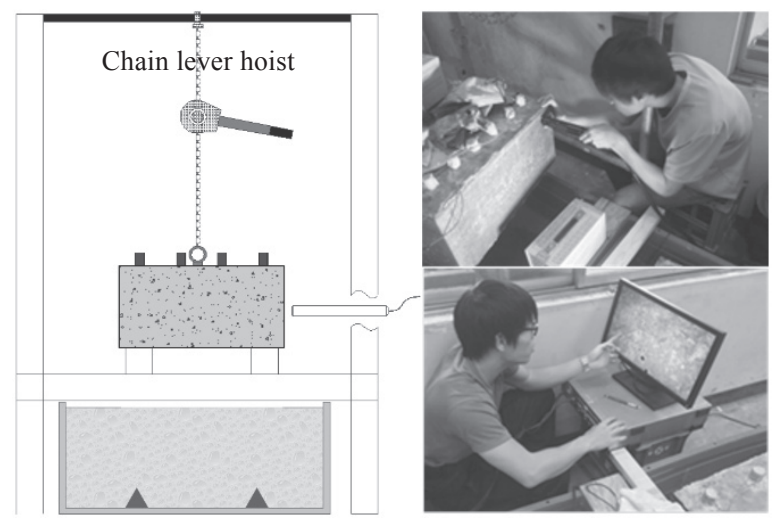

Fig 3 Measurement of crack width using digital microscope

電流量に比例するとして推定するため, 各鉄筋のリード線に $2 \Omega$ の 抵抗を接続し，この抵抗間の電圧を 1 時間ごとにデータロガーで計 測した。この電圧から各鉄筋に導入される電流を算定し, 促進試験 期間中 (約 3 か月間) における積算電流量を随時求めた。また, 横補 強筋ひずみもデータロガーを使用し，1 時間ごとに各ゲージのひず みを計測した。

表面ひび割れ幅の測定は, 腐食ひび割れの発生以降, 分解能 1/100mm のデジタルマイクロスコープを用いて, Fig. 3 に示すよう に試験体を塩水より引き上げた状態で適宜行った。

\section{3 促進腐食実験結果および考察}

\section{1 腐食鉄筋の質量減少}

促進腐食実験終了後，コンクリートから鉄筋を取り出し，10\%ク エン酸アンモニウム水溶液中に 24 時間浸漬させた。その後, ワイヤ ーブラシで腐食生成物を完全に除去した鉄筋腐食後の質量を計測し, 健全時の質量と比較することによって各鉄筋の質量減少量を実測し た。Table 4 に各腐食鉄筋の実測による単位面積当たりの質量減少量 $W_{\text {loss }}\left(\mathrm{mg} / \mathrm{cm}^{2}\right)$ および括弧内に健全鉄筋からの質量減少率 $(\%)$ を太字 で示す。さらに Table 4 には, 積算電流量からファラデーの電気分解 の法則 (4)式を用いて算出した単位面積当たりの最終的な質量減少 量 $W_{\text {cal }}\left(\mathrm{mg} / \mathrm{cm}^{2}\right)$, 質量減少率 $(\%)$ および最終積算電流量 $(\mathrm{mA} \cdot \mathrm{hr} /$ $\left.\mathrm{cm}^{2}\right)$ を比較のため示している。質量減少量 $\left(\mathrm{mg} / \mathrm{cm}^{2}\right)$ から質量減少率 (\%)への換算係数を Appendix table 1 に示す。 


$$
W_{c a l}=\frac{M_{F e} i_{c o r r} t}{n F}
$$

ここに, $M_{F e}$ は鉄のモル質量 $(55.8 \mathrm{~g} / \mathrm{mol}), i_{c o r r}$ は電流密度 $\left(\mathrm{mA} / \mathrm{cm}^{2}\right)$, $t$ は通電時間 $(\mathrm{s})$ である。また, $F$ はファラデー定数 $(96485 \mathrm{C} / \mathrm{mol})$ を 表し, $n$ は鉄のイオン価 $(=2)$ である。

主筋の腐食量は，隅筋と中段筋とで腐食量に差異があったため, 隅角部主筋 (Corner) と中間部主筋 (Intermediate) に分けて表し, 横補 強筋の腐食量は 3 本の平均である。隅角部主筋, 中間部主筋および 横補強筋の全試験体を通した平均值を最終行に示す。

中間部主筋に対して隅角部主筋の実測腐食量は全体の平均で約 2 倍となった。これは中間部では塩化物イオンや酸素の供給が 1 方向 からであるのに対し，隅角部では 2 方向となり，より電気が流れや すく (Table 4 に示す最終積算電流量を参照), 腐食に対して厳しい条 件になっていると考えられる。Aris ${ }^{3)}$ の実験においても，隅角部主筋 の腐食量は中間部に対して 1.5 倍となったが, $\mathrm{NaCl}$ 水溶液を吸収す るスポンジを梁試験体の下面に押し当て, 1 方向から塩化物イオン が侵入する促進腐食方法を採用したため, 差異が小さくなったと思 われる。隅角部が外面に露出し, 2 方向から塩化物イオンや酸素が 供給される RC 柱梁部材の場合は, 隅角部の腐食量は中間部主筋の 2 倍と評価するのが妥当であると考えられる。

また，積算電流量から計算した腐食量に対する実測した腐食量の 比 $W_{\text {loss }} / W_{\text {cal }}$ を比較すると, 主筋は平均で 0.42 (隅角部) と 0.32 (中間 部)であるのに対し, 横補強筋は平均で 1.7 となり, 主筋より 4 倍以 上大きくなっている。この原因として, 鉄筋表面で生じている腐食 反応が横補強筋ではアノード側へ, 主筋ではカソード側へ偏ってい くマクロセルが形成されたと考えられる。マクロセルに関してはこ

Table 4 Comparison of measured and estimated corrosion rates

\begin{tabular}{|c|c|c|c|c|c|c|c|c|c|}
\hline \multirow{4}{*}{ Specimen } & \multicolumn{6}{|c|}{ Longitudinal bars } & \multirow{2}{*}{\multicolumn{3}{|c|}{ Transverse bar }} \\
\hline & \multicolumn{3}{|c|}{ Corner } & \multicolumn{3}{|c|}{ Intermediate } & & & \\
\hline & $\mathbf{W}_{\text {loss }}$ & $\mathrm{W}_{\text {cal }}$ & $i_{\text {corr }} \cdot t$ & $\mathbf{W}_{\text {loss }}$ & $\mathrm{W}_{\mathrm{cal}}$ & $i_{\text {corr }} \cdot t$ & $\mathbf{W}_{\text {loss }}$ & $\mathrm{W}_{\mathrm{cal}}$ & $\overline{i_{\text {corr }} \cdot t}$ \\
\hline & \multicolumn{2}{|c|}{$\begin{array}{c}\mathrm{mg} / \mathrm{cm}^{2} \\
(\%)\end{array}$} & $\frac{\mathrm{mA} \cdot \mathrm{hr}}{\mathrm{cm}^{2}}$ & \multicolumn{2}{|c|}{$\begin{array}{c}\mathrm{mg} / \mathrm{cm}^{2} \\
(\%)\end{array}$} & $\frac{\mathrm{mA} \cdot \mathrm{hr}}{\mathrm{cm}^{2}}$ & \multicolumn{2}{|c|}{$\begin{array}{c}\mathrm{mg} / \mathrm{cm}^{2} \\
(\%)\end{array}$} & $\frac{\mathrm{mA} \cdot \mathrm{hr}}{\mathrm{cm}^{2}}$ \\
\hline $12-\mathrm{F}_{\mathrm{c}} 24$ & $\begin{array}{c}50 \\
(0.80)\end{array}$ & $\begin{array}{c}126 \\
(2.0)\end{array}$ & 121 & \begin{tabular}{|c|}
39 \\
$(0.62)$
\end{tabular} & $\begin{array}{c}98 \\
(1.6) \\
\end{array}$ & 94 & \begin{tabular}{|c|}
154 \\
$(5.0)$ \\
\end{tabular} & $\begin{array}{c}68 \\
(2.2) \\
\end{array}$ & 65 \\
\hline $12-\mathrm{F}_{\mathrm{c}} 48$ & \begin{tabular}{|c|}
$\mathbf{5 7}$ \\
$(\mathbf{0 . 9 1})$ \\
\end{tabular} & \begin{tabular}{|c}
104 \\
$(1.7)$ \\
\end{tabular} & 100 & \begin{tabular}{|c|}
19 \\
$(0.30)$
\end{tabular} & $\begin{array}{c}115 \\
(1.8)\end{array}$ & 110 & $\begin{array}{c}141 \\
(4.5)\end{array}$ & $\begin{array}{c}94 \\
(3.0) \\
\end{array}$ & 91 \\
\hline $12-\mathrm{F}_{\mathrm{c}} 72$ & \begin{tabular}{|c|}
39 \\
$(0.62)$ \\
\end{tabular} & $\begin{array}{c}93 \\
(1.5) \\
\end{array}$ & 90 & \begin{tabular}{|c|}
27 \\
$(0.43)$ \\
\end{tabular} & $\begin{array}{c}69 \\
(1.1) \\
\end{array}$ & 66 & $\begin{array}{c}112 \\
(3.6) \\
\end{array}$ & $\begin{array}{c}108 \\
(3.5) \\
\end{array}$ & 103 \\
\hline $20-\mathrm{T}-\mathrm{F}_{\mathrm{c}} 24$ & $\begin{array}{c}82 \\
(1.6) \\
\end{array}$ & $\begin{array}{c}106 \\
(2.1)\end{array}$ & 102 & \begin{tabular}{|c|}
50 \\
$(1.0)$ \\
\end{tabular} & $\begin{array}{c}108 \\
(2.2)\end{array}$ & 104 & $\begin{array}{c}212 \\
(8.5)\end{array}$ & $\begin{array}{c}62 \\
(2.5) \\
\end{array}$ & 60 \\
\hline $20-\mathrm{T}-\mathrm{F}_{\mathrm{c}} 48$ & \begin{tabular}{|c|}
113 \\
$(2.3)$ \\
\end{tabular} & $\begin{array}{c}167 \\
(3.4) \\
\end{array}$ & 161 & \begin{tabular}{|c|}
46 \\
$(0.92)$ \\
\end{tabular} & $\begin{array}{c}109 \\
(2.2) \\
\end{array}$ & 105 & \begin{tabular}{|c|}
219 \\
$(8.8)$ \\
\end{tabular} & $\begin{array}{c}84 \\
(3.4) \\
\end{array}$ & 80 \\
\hline $20-\mathrm{T}-\mathrm{F}_{\mathrm{c}} 72$ & $\begin{array}{c}60 \\
(1.2)\end{array}$ & $\begin{array}{c}141 \\
(2.8)\end{array}$ & 135 & $\begin{array}{c}29 \\
(0.58)\end{array}$ & $\begin{array}{c}73 \\
(1.5)\end{array}$ & 70 & $\begin{array}{c}134 \\
(5.4)\end{array}$ & $\begin{array}{c}82 \\
(3.3)\end{array}$ & 78 \\
\hline $8-\mathrm{F}_{\mathrm{c}} 48$ & $\begin{array}{c}43 \\
(0.58)\end{array}$ & $\begin{array}{c}130 \\
(1.7)\end{array}$ & 125 & $\begin{array}{c}28 \\
(0.38)\end{array}$ & $\begin{array}{c}111 \\
(1.5)\end{array}$ & 107 & $\begin{array}{c}195 \\
(6.3)\end{array}$ & $\begin{array}{c}143 \\
(4.6)\end{array}$ & 137 \\
\hline $20-\mathrm{F}_{\mathrm{c}} 48$ & \begin{tabular}{|c|}
46 \\
$(0.92)$
\end{tabular} & $\begin{array}{c}167 \\
(3.5)\end{array}$ & 161 & \begin{tabular}{|c|}
44 \\
$(0.88)$
\end{tabular} & $\begin{array}{c}109 \\
(2.2)\end{array}$ & 105 & $\begin{array}{c}132 \\
(4.2)\end{array}$ & $\begin{array}{c}84 \\
(2.7)\end{array}$ & 80 \\
\hline $12-\mathrm{C} 20$ & $\begin{array}{c}48 \\
(0.77)\end{array}$ & $\begin{array}{c}190 \\
(3.0) \\
\end{array}$ & 183 & $\begin{array}{c}17 \\
(0.27)\end{array}$ & $\begin{array}{c}132 \\
(2.1) \\
\end{array}$ & 127 & $\begin{array}{c}170 \\
(5.5) \\
\end{array}$ & $\begin{array}{c}67 \\
(2.2) \\
\end{array}$ & 65 \\
\hline $12-\mathrm{C} 60$ & $\begin{array}{c}29 \\
(0.46)\end{array}$ & $\begin{array}{c}126 \\
(2.0) \\
\end{array}$ & 121 & \begin{tabular}{|c|}
20 \\
$(0.32)$
\end{tabular} & $\begin{array}{c}82 \\
(1.3) \\
\end{array}$ & 79 & \begin{tabular}{|c|}
97 \\
$(3.1)$ \\
\end{tabular} & $\begin{array}{c}120 \\
(3.8) \\
\end{array}$ & 115 \\
\hline Average & $\begin{array}{c}\mathbf{5 7} \\
\mathbf{( 1 . 0 )} \\
\end{array}$ & $\begin{array}{c}135 \\
(2.4)\end{array}$ & 130 & \begin{tabular}{|c|}
32 \\
$(0.57)$
\end{tabular} & $\begin{array}{c}101 \\
(1.8)\end{array}$ & 97 & $\begin{array}{c}157 \\
(5.5) \\
\end{array}$ & $\begin{array}{c}91 \\
(3.1)\end{array}$ & 87 \\
\hline
\end{tabular}

Numeric values in parentheses indicate mass loss in percentage.
れまで多くの研究 ${ }^{11)}$ が行われており, 部材位置によって塩化物イオ ン濃度が不均一である場合には塩化物イオン濃度の高い部分の鉄筋 においてアノード反応が卓越し，これ以外の部分にある鉄筋でカy 一ド反応が起こるマクロセル回路が形成されることが知られている。 本促進腐食試験では, 塩害環境下の $\mathrm{RC}$ 構造物に, 外部から浸透す る塩化物イオン量が部材位置によって不均一となることを考慮し, 2. 2 項で述べたように，(1)式に基づいて主筋と横補強筋それぞれの かぶり位置における塩化物イオン濃度を評価し, 主筋側の電流を ON/OFF している。このことにより塩化物イオン濃度の高い横補強 筋の腐食速度が加速され, 積算電流量から算出した予測腐食量より 大きな腐食量となったと考えられる。

上述のように，実測による腐食量とファラデー則による腐食量に 大きな差異があったため, 促進腐食中の腐食量は, 次のように推定 した換算值(Calibrated corrosion)を，以降使用する。本実験における 各鉄筋の正確な腐食量は，促進試験終了後の実測值のみのため，通 電前(積算電流量ゼロ) の腐食量をゼロとし，最終積算電流量と実測 腐食量の点を直線で結び（線形補間）, 積算電流量を尺度として, 各時点の積算電流量から各鉄筋の腐食量を推定 ${ }^{3)}$ した。

\section{2 腐食ひび割れの発生}

促進腐食を開始してから 3 日後, コンクリート強度の低い $\mathrm{F}_{\mathrm{c}} 24$ 試 験体, 続いてかぶりの小さい $12-\mathrm{C} 20$ 試験体の上部横補強筋位置に沿 って腐食膨張ひび割れが発生した。かぶりの大きい 12-C60 試験体を 除くす心゙ての試験体は，横補強筋上の腐食ひび割れ発生が主筋上の 腐食ひび割れより先行した。Table 5 に各試験体の表面に腐食ひび割 れが最初に観測された位置と対応する鉄筋の換算腐食量およびひび 割れ幅を横補強筋 (Trans. 上段) と主筋 (Longi. 下段)に分けて示す。 主筋上の腐食ひび割れは最終腐食量の大きい隅角部位置で発生し, 最初の英文字はひび割れが発生した面に垂直な方位を表し，次の英 文字はその面内の方向を表している。

さらに，塩害物を含んだコンクリート中の鉄筋腐食速度 (\%/年) は,

Table 5 Location, corrosion rate and crack width at first cracking

\begin{tabular}{|c|c|c|c|c|c|}
\hline \multirow{2}{*}{ Specimen } & \multirow{2}{*}{ Location } & \multicolumn{3}{|c|}{ Corrosion rate $\left(\mathrm{mg} / \mathrm{cm}^{2}\right)$} & \multirow{2}{*}{$\begin{array}{c}\text { Crack width } \\
(\mathrm{mm})\end{array}$} \\
\hline & & Test & Eq.(5) & $\mathrm{T} /(5)$ & \\
\hline \multirow{2}{*}{$12-\mathrm{F}_{\mathrm{c}} 24$} & Trans.-top & 14 & 24 & 0.57 & 0.08 \\
\hline & Longi.-SE & 17 & 17 & 1.00 & 0.08 \\
\hline \multirow{2}{*}{$12-\mathrm{F}_{\mathrm{c}} 48$} & Trans.-bottom & 38 & 25 & 1.52 & 0.01 \\
\hline & Longi.-EN & 46 & 18 & 2.62 & 0.12 \\
\hline \multirow{2}{*}{$12-\mathrm{F}_{\mathrm{c}} 72$} & Trans.-bottom & 28 & 25 & 1.13 & 0.02 \\
\hline & Longi.-SW & 23 & 18 & 1.30 & 0.08 \\
\hline \multirow{2}{*}{$20-\mathrm{T}-\mathrm{F}_{\mathrm{c}} 24$} & Trans.-top & 17 & 29 & 0.60 & 0.01 \\
\hline & Longi.-ES & 24 & 20 & 1.20 & 0.12 \\
\hline \multirow{2}{*}{$20-\mathrm{T}-\mathrm{F}_{\mathrm{c}} 48$} & Trans.-top & 75 & 31 & 2.42 & 0.06 \\
\hline & Longi.-SE & 49 & 21 & 2.30 & 0.14 \\
\hline \multirow{2}{*}{$20-\mathrm{T}-\mathrm{F}_{\mathrm{c}} 72$} & Trans.-bottom & 51 & 31 & 1.66 & 0.13 \\
\hline & Longi.-SE & 23 & 21 & 1.10 & 0.02 \\
\hline \multirow{2}{*}{$8-\mathrm{F}_{\mathrm{c}} 48$} & Trans.-top & 61 & 24 & 2.51 & 0.03 \\
\hline & Longi.-WS & 17 & 14 & 1.20 & 0.15 \\
\hline \multirow{2}{*}{$20-\mathrm{F}_{\mathrm{c}} 48$} & Trans.-bottom & 49 & 25 & 1.97 & 0.01 \\
\hline & Longi.-NE & 33 & 22 & 1.50 & 0.11 \\
\hline \multirow{2}{*}{$12-\mathrm{C} 20$} & Trans.-top & 18 & 12 & 1.57 & 0.03 \\
\hline & Longi.-ES & 18 & 11 & 1.62 & 0.05 \\
\hline \multirow{2}{*}{$12-\mathrm{C} 60$} & Trans.-top & 75 & 38 & 2.01 & 0.10 \\
\hline & Longi.-EN & 23 & 24 & 0.96 & 0.05 \\
\hline
\end{tabular}

Note: SE indicates a location on the east side facing the south. 


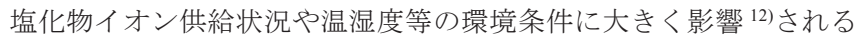
が，腐食ひび割れがコンクリート表面に到達する鉄筋腐食量 $W_{c r}$ $\left(\mathrm{mg} / \mathrm{cm}^{2}\right)$ に関しては, かぶりと鉄筋径の比に依存する簡便な式が提 案 ${ }^{13)}$ れれてる。(5)式による腐食量も比較のため Table 5 に示す。

$$
W_{c r}=10 \times d / \phi
$$

ここに $, d:$ かぶり $(\mathrm{mm}), \phi:$ 鉄筋径 $(\mathrm{mm})$ である。

コンクリート強度の低い $\mathrm{F}_{\mathrm{c}} 24$ 試験体の上部横補強筋位置の腐食 膨張ひび割れが早期に発生したのは，コンクリート強度やブリージ ングによるセメント硬化体の空隙が影響したと思われる。しかしな がらコンクリート強度が高くなるとブリージングの影響が少なくな り, 下部横補強筋位置に沿う腐食膨張ひび割れが先行している。こ れは Aris ら ${ }^{3)}$ や Kukrit ら ${ }^{9)}$ が指摘するように, セメント硬化体の空 隙が少なくなると腐食生成物が空隙に拡散できず，周囲のコンクリ 一トに対する膨張圧が高くなるため，より少ない腐食量でひび割れ を形成する可能性が高くなることに起因していると思われる。さら にコンクリート強度の異なる試験体 12-または 20-T- $\mathrm{F}_{\mathrm{c}} 24, \mathrm{~F}_{\mathrm{c}} 48, \mathrm{~F}_{\mathrm{c}} 72$ の腐食ひび割れが表面に到達する腐食量を比較すると, $\mathrm{F}_{\mathrm{c}} 24$ が最も 小さく, $\mathrm{F}_{\mathrm{c}} 48$ で最大となり, $\mathrm{F}_{\mathrm{c}} 72$ では再び腐食量が小さくなる傾向 を示した。コンクリート強度が高くなると引張強度の増加によりひ び割れに対する抵抗性も増加するが，セメントペーストの空隙量 ${ }^{14)}$ が少なくなり，腐食生成物がひび割れ面に集中寸る。その結果 $\mathrm{F}_{\mathrm{c}} 72$ では強度が上昇したにもかかわらず表面ひび割れ発生時の腐食量が 小さくなったと考えられる。またコンクリート強度が同じでかぶり の異なる試験体 12-C $20,12-\mathrm{F}_{\mathrm{c}} 48,12-\mathrm{C} 60$ を比較すると, かぶりが 20 $\mathrm{mm}$ から $20 \mathrm{~mm}$ 厚くする毎に, 横補強筋上の腐食ひび割れ発生時の 腐食量は倍増していることが分かる。

(5)式による推定腐食量に対する実験による換算腐食量の比 $\mathrm{T} /(5)$ は，0.6 2.6 と大きなばらつきを示している。そこで腐食ひび割れが 観測された全主筋および上部と下部横補強筋のひび割れ発生時の換 算腐食量を $d / \phi$ に対して Fig. 4 に示寸。Fig. 4 には, 他の研究者のデ 一タも白抜きで併せてプロットしており, 実線は(5)式, 破線は(5)式 の 3 倍の腐食量を示している。実験データの大部分は実線と破線の 間にあり, 実験結果は(5)式による腐食ひび割れ発生時の推定腐食量 より大きな腐食量を示している。本実験では, 促進腐食実験終了

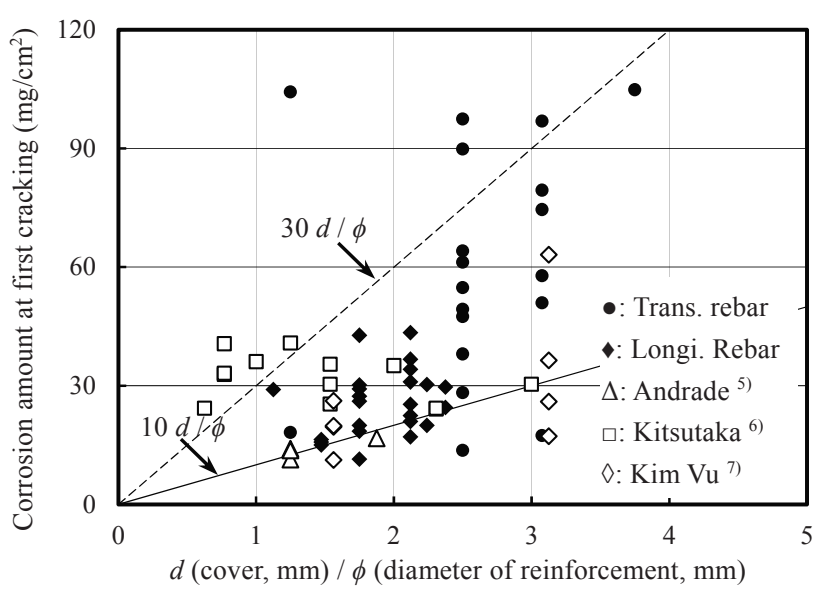

Fig. 4 Internal crack surfaces and corrosion products migration
後の質量減少のみ実測し, 実験中の腐食量は積算電流量に比例する と仮定した換算腐食量を用いているが，表面ひび割れ発生までは塩 化物イオンや酸素の供給が少なく, 腐食速度が小さくなることも考 えられる。このことによって, 実験による腐食量が(5)式より大きく なった可能性もあり, ひび割れ発生までの腐食量に関しては, 今後 詳細に検討する必要がある。

さらに，最初に腐食ひび割れを確認した時点のひび割れ幅は，確 認が遅れた 20-T-F 72 の横補強筋上のひび割れ，および横補強筋か ら流出した腐食生成物の影響で観測が難しくなった一部の主筋上の ひび割れを除くと，すべて $0.1 \mathrm{~mm}$ 以下であった。

\section{3 腐食ひび割れの進展挙動}

Fig. 5 に促進腐食開始から約 1 か月経過後の基準試験体 12-F 48 に 対し，コンクリート強度の異なる $12-\mathrm{F}_{\mathrm{c}} 24$ と $12-\mathrm{F}_{\mathrm{c}} 72$ 試験体およびか ぶり厚さの異なる 12-C20 と 12-C60 試験体の腐食ひび割れ性状を比 較して示す。いずれの試験体も同じ電圧 $(10 \mathrm{~V})$ を用いて促進腐食試験 を行っているが, 電流は各試験体さらに各鉄筋によって異なるため, 積算電流量に基づいて換算した各試験体の主筋と横補強筋の平均腐 食量を Table 6 に示す。主筋と横補強筋ともに, コンクリート強度が 高いほど，またかぶりが厚いほどコンクリート内部への塩化物イオ ンの侵入に対する抵抗性が高くなるため, 積算電流量が小さくなり 換算腐食量も小さくなっている。

Fig.5 の写真から, 換算腐食量が小さくなった高強度コンクリート 12- $\mathrm{F}_{\mathrm{c}} 72$ 試験体および厚いかぶり 12-C60 試験体の表面には，コンク リートの劣化の予兆であるエフロレッセンスが見られるものの腐食 生成物の流出はなかった。一方， 12- $\mathrm{F}_{\mathrm{c}} 24$ と 12-C20 試験体は表面に 腐食ひび割れが見られるとともに, 大量の腐食生成物がひび割れを 通して流出していることがわかる。

Fig.6 に促進腐食試験終了後の試験体内部における腐食生成物の 浸透状況とひび割れ面の形成の様子を示す。Fig.6 (a)に示すように, 腐食生成物は主筋間および横補強筋間に大量に残留しており, かぶ りコンクリートをコア部から切り離すようなひび割れが形成されて いる。このひび割れ進展のため, タガネとハンマーによる打撃によ って容易にかぶりコンクリートを外すことができた。腐食生成物は 横補強筋間で連結寸るひび割れ面および上下の横補強筋からかぶり コンクリート表面へ達するひび割れ面に最も多く残留していた。こ のことから鉄筋に沿う腐食ひび割れが発生しなかった中間部の主筋 および横補強筋の腐食生成物も, 浸透の容易な上下の横補強筋上の 腐食ひび割れを通してコンクリート表面へ流出したと思われる。

Fig.6 (b)は, かぶりコンクリートと鉄筋を取り外した後, コア側コ ンクリートをダイアモンドカッターを用いて切断した断面である。 横補強筋よりコア側では, 腐食生成物の浸透によるひび割れ進展は 確認できず, コア側への腐食生成物の侵入がないことを示している。 上下の横補強筋上の腐食ひび割れが先行してコンクリート表面まで 達したために, 腐食生成物がコア側へ浸透せず, 抵抗の少ないひび 割れ面が腐食生成物の流出経路となったと想定される。

Fig6 (c)は，塩化物イオンが侵入するかぶり側とコア側の鉄筋の腐 食性状を比較するため, 最も太径の $8-\mathrm{F}_{\mathrm{c}} 48$ 試験体の主筋 (D38)を示 しているが，その他の鉄筋も同様の腐食性状となった。かぶり側の 表面には一部孔食も見られるが，コア側の表面はほとんど腐食して いない。以上のことから，塩害のように短期間に鉄筋腐食が進行す 

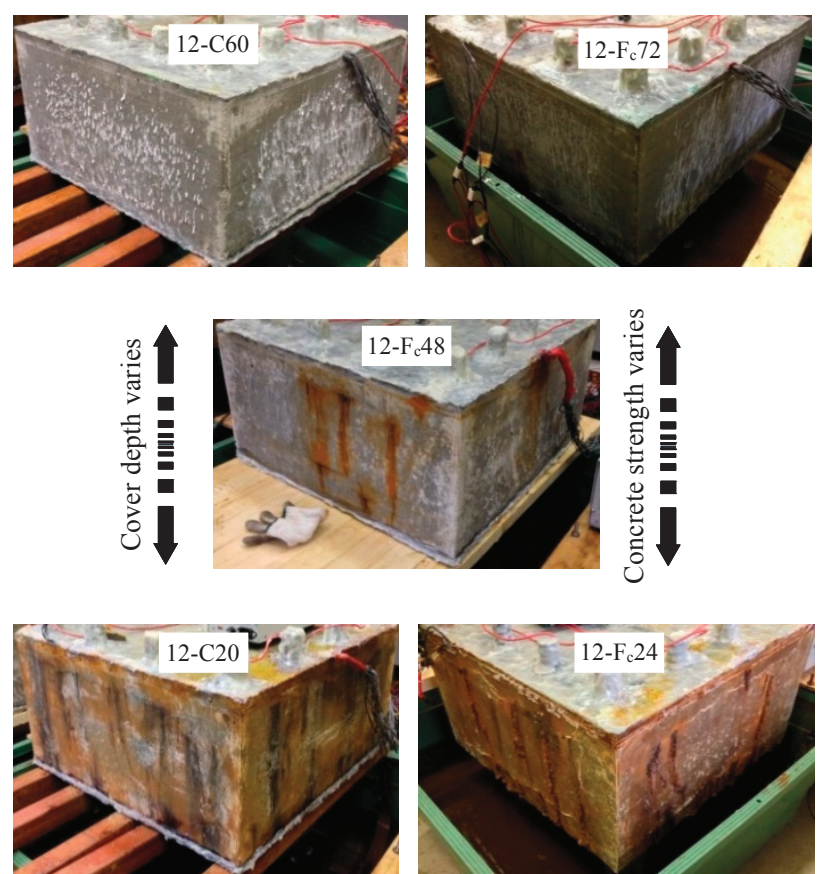

Fig. 5 Comparison at about one month passed on accelerated corrosion

Table 6 Corrosion amount after about one month

\begin{tabular}{c|c|c}
\hline \multirow{2}{*}{$\begin{array}{c}\text { Specimens } \\
30 \text { days passed }\end{array}$} & \multicolumn{2}{|c}{ Average Calibrated corr. amount $\left(\mathrm{mg} / \mathrm{cm}^{2}\right)$} \\
\cline { 2 - 3 } & Longitudinal steel bar & Transverse steel bar \\
\hline $12-\mathrm{F}_{\mathrm{c}} 24$ & 45 & 150 \\
\hline $12-\mathrm{F}_{\mathrm{c}} 48$ & 21 & 61 \\
\hline $12-\mathrm{F}_{\mathrm{c}} 72$ & 12 & 39 \\
\hline $12-\mathrm{C} 20$ & 33 & 170 \\
\hline $12-\mathrm{C} 60$ & 8.0 & 29 \\
\hline
\end{tabular}

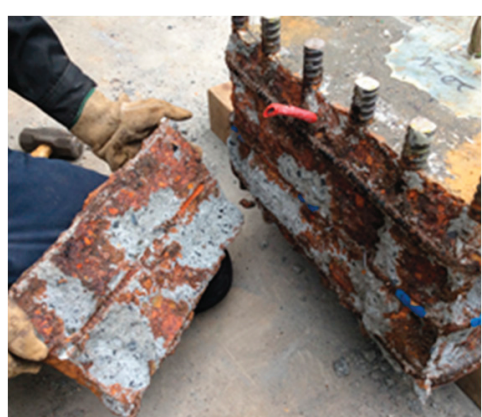

(a) Cut off a cover concrete

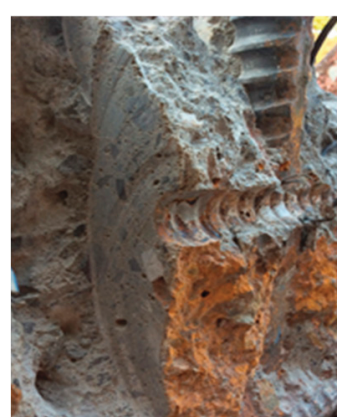

(b) No cracked core concrete

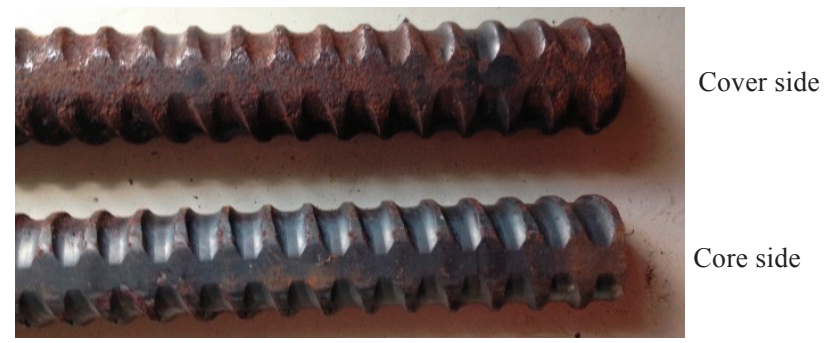

(c) Appearance of corroded steel in cover side and core side

Fig. 6 Infiltration by corrosion products and corroded main bars
る場合, コアコンクリートの強度特性に及ぼす影響は限定的となり， かぶりコンクリートの剥落，鉄筋の断面減少による曲げ而力，横補 強筋のひずみ上昇によるせん断耐力が問題になると思われる。

\section{4 最終ひび割れ性状}

Fig. 7 に各試験体の促進腐食試験終了時において, 最大ひび割れ 幅を記録した面のひび割れ図を示す。E，W， S， N は東西南北の方 位を示し，○と数值で最大ひび割れの位置と幅 $(\mathrm{mm})$ を記している。 Fig. 7 に示すように，主筋上の腐食ひび割れが先行した 12-C60 以外 の最大ひび割れ幅は，上下に配した横補強筋上で記録されており， 中間に配した横補強筋および主筋に沿う腐食ひび割れは少なくなっ ている。これは前述したように，上下の横補強筋に沿ったコンクリ 一ト表面の腐食ひび割れが先行し，流出が容易になったことによっ て，腐食生成物がこのひび割れ面に集中したことと整合している。

また，主筋上の腐食ひび割れは全試験体を通して隅角部主筋のみ に現れた。Table 4 に示した通り，中間部主筋に対して隅角部主筋の 質量減少率が 2 倍以上となったことに起因していると考えられる。

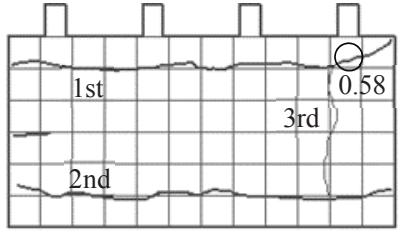

$12-\mathrm{F}_{\mathrm{c}} 24(\mathrm{E})$

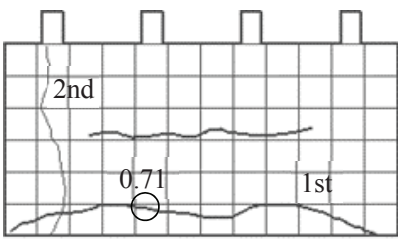

$12-\mathrm{F}_{\mathrm{c}} 72(\mathrm{~S})$

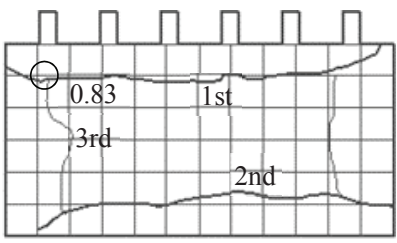

$20-\mathrm{T}-\mathrm{F}_{\mathrm{c}} 48(\mathrm{~S})$

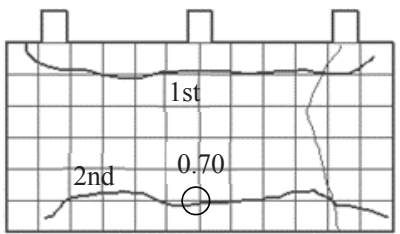

$8-\mathrm{F}_{\mathrm{c}} 48(\mathrm{~W})$

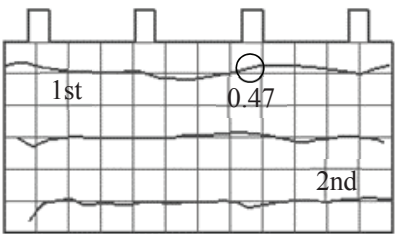

$12-\mathrm{C} 20(\mathrm{~N})$

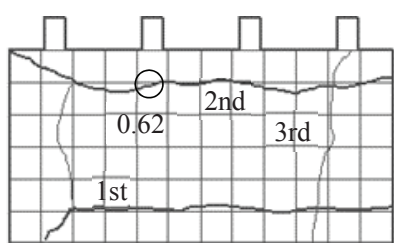

$12-\mathrm{F}_{\mathrm{c}} 48(\mathrm{E})$

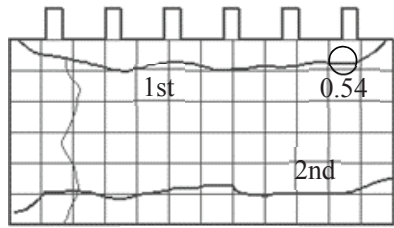

$20-\mathrm{T}-\mathrm{F}_{\mathrm{c}} 24(\mathrm{E})$

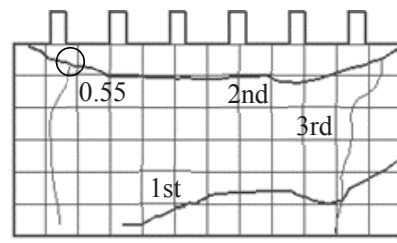

$20-\mathrm{T}-\mathrm{F}_{\mathrm{c}} 72(\mathrm{~S})$

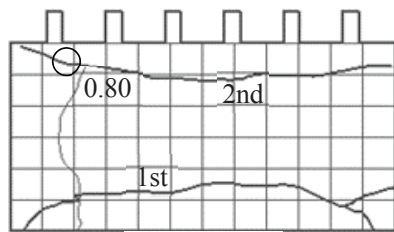

$20-\mathrm{F}_{\mathrm{c}} 48(\mathrm{~S})$

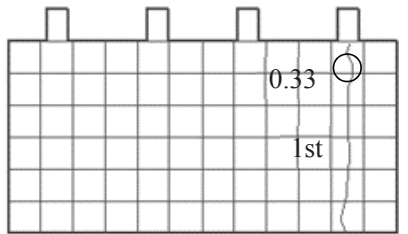

$12-\mathrm{C} 60(\mathrm{E})$ $\bigcirc$ : Largest crack point and maximum crack width (unit: $\mathrm{mm}$ )

Fig. 7 Crack patterns at final corrosion stages 


\section{5 腐食量とひび割れ幅の関係}

前項で述べたように, 主筋の腐食量は横補強筋に比べて小さく, さらにその腐食生成物の一部は早期に形成された上下の横補強筋に 沿う腐食ひび割れを通してコンクリート表面に流出したため，主筋 に沿う腐食ひび割れの成長は比較的小さくなった。それ故，コンク リート表面の腐食ひび割れが最も拡幅した横補強筋 (Fig. 7 参照)に ついて, 腐食量とひび割れ挙動に影響を与える各パラメータを考察 する。横補強筋上の腐食ひび割れ幅は, 主筋からの腐食生成物を含 んでいるため, 単筋で行う腐食実験より大きくなる可能性があるが, 本試験体は実構造物と同様な配筋であることを考慮すると, 妥当な 評価基準になると思われる。

Fig. 8 にコンクリート強度(a) 12- $\mathrm{F}_{\mathrm{c}} 24, \mathrm{~F}_{\mathrm{c}} 48, \mathrm{~F}_{\mathrm{c}} 72$ と(b) 20-T- $\mathrm{F}_{\mathrm{c}} 24$, $\mathrm{F}_{\mathrm{c}} 48, \mathrm{~F}_{\mathrm{c}} 72$, 主筋径(c) 8，12，20- $\mathrm{F}_{\mathrm{c}} 48$ およびかぶり(d) 12-C20，C40, C60 によるひび割れ挙動を比較して示す。横軸は対象とする横補強 筋 (12- $\mathrm{F}_{\mathrm{c}} 72 ， 8-\mathrm{F}_{\mathrm{c}} 48$ 試験体は下部，その他は上部横補強筋)の換算腐 食量 $\left(\mathrm{mg} / \mathrm{cm}^{2}\right)$, 縦軸は対象とする横補強筋上の各面で計測した最大 ひび割れ幅の平均值である。

Fig. 8 の全体を通して, Table 5 に示したひび割れ発生時の腐食量 に相当する 20 から $70 \mathrm{mg} / \mathrm{cm}^{2}$ 程度からひび割れ幅が増加している。 しかしながらひび割れ幅が $0.2 \mathrm{~mm}$ を超えると, ひび割れを通して腐 食生成物の流出が多くなるため(Fig.6), ひび割れの拡幅速度が低下 する傾向がある。

Fig.8 (a)と(b)から, コンクリート強度が低い $\mathrm{F}_{\mathrm{c}} 24$ 試験体は腐食量 が $200 \mathrm{mg} / \mathrm{cm}^{2}$ 程度までひび割れ幅の増加が小さくなっている。これ は水セメント比が大きくなるとセメントペースト内の空隙が増加し, 腐食生成物が鉄筋周りの空隙に拡散することに起因していると考え られる。一方, コンクリート強度が高くなると, セメントペースト 内の空隙量が減少し, 腐食生成物がひび割れ面に集中寸るため, よ り少ない腐食量でひび割れが急速に拡幅している。また Fig.8(c)は, 主筋径および本数の異なる試験体の比較であるが，ひび割れ幅の上
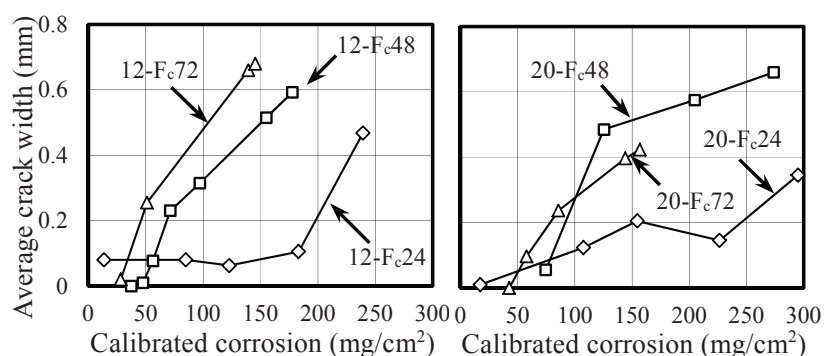

(a) Concrete strength (12-bars)

(b) Concrete strength (20-bars)
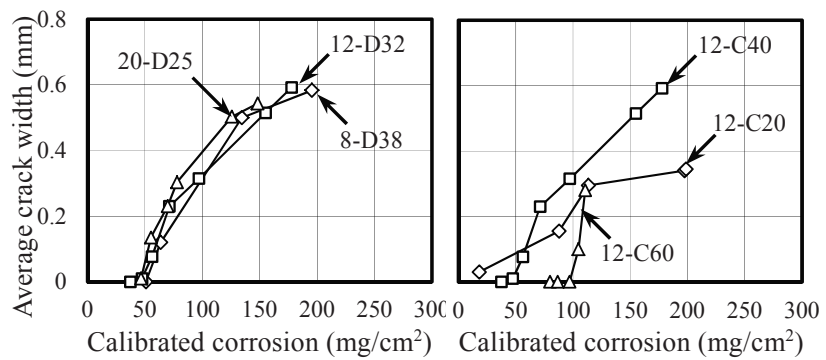

(c) Main bar arrangement $\left(\mathrm{F}_{\mathrm{c}} 48\right)$

(d) Covering depth $\left(\mathrm{F}_{\mathrm{c}} 48\right)$
昇傾向 (グラフの傾き) はほぼ同程度であった。各試験体のコンクリ 一ト強度 $\mathrm{F}_{\mathrm{c}} 48$, かぶり $40 \mathrm{~mm}$ および横補強筋 D 16 が同一であり, さ らに主筋量も同じであることを考慮すると, 想定できる結果である。 さらに Fig.8(d)は，かぶりの異なる試験体の比較であるが，かぶりの 小さい $\mathrm{C} 20$ 試験体は，腐食生成物がかぶりコンクリートのひび割れ を通して流出寸るのが容易になり，ひび割れの拡幅は小さくなって いる。一方，かぶりの大きい C60 試験体は，かぶりコンクリートが 多くの腐食生成物を吸収するため，腐食ひび割れが表面に達するま でに多くの腐食量を必要としている。

\section{6 横補強筋のひずみ挙動}

Aris $ら^{3)}$ の RC 梁の促進腐食実験では，ひずみゲージの保護と一 定拘束力の確保のため，横補強筋にビニールテープを巻いて防食処 置を施した。その結果，主筋に沿う腐食ひび割れのみ発生し，ひび 割れの拡幅と共にひび割れを横切る横補強筋のひずみが上昇した。 このように，ひび割れ幅と補強筋ひずみには強い相関があり ${ }^{15)}$ ，横 補強筋のひずみ挙動を検討することによって，コンクリート内部の ひび割れ損傷を推定することができる。そこで Fig. 9 に，各試験体 で最大ひずみを記録した横補強筋のひずみとそのひずみ上昇に最も 影響を及ぼす横補強筋に接する主筋の平均腐食量との関係を示す。

コンクリート強度の異なるひずみ挙動を比較した Fig.9(a)と(b)か ら，コンクリート強度が高いほど最大横補強筋ひずみの上昇が大き くなる傾向がある。これは前項で述べたように，水セメント比が小 さい場合には腐食生成物のセメントペースト中の空隙への侵入が少 なくなるため，ひび割れ損傷が大きくなったことに起因していると 思われる。 $F_{\mathrm{c}} 72$ 試験体では, ひずみが $400 \mu$ を超え, 通常強度鉄筋の 降伏ひずみの $25 \%$ に達しているが，かぶりコンクリートの腐食ひび 割れ面を通して腐食生成物が流出すると，ひずみ上昇率も鈍化して いる。横補強筋を防食した Aris ら 3)の RC 梁実験では, 腐食生成物 が横補強筋上の腐食ひび割れを通して流出しなかったため, 横補強 筋のひずみは $800 \mu$ 以上に達したが，実構造物を想定し，横補強
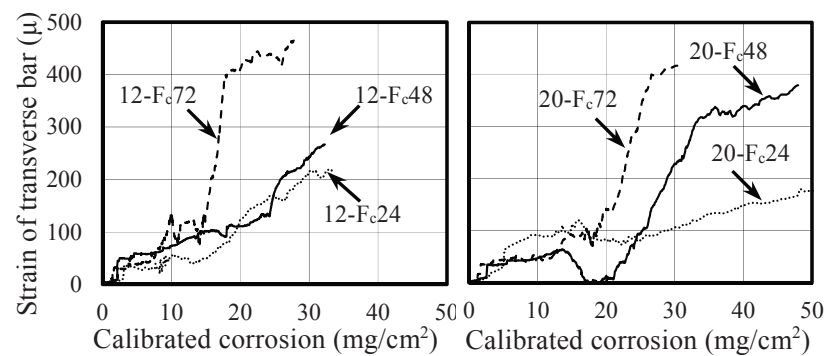

(a) Concrete strength (12-bars)

(b) Concrete strength (20-bars)
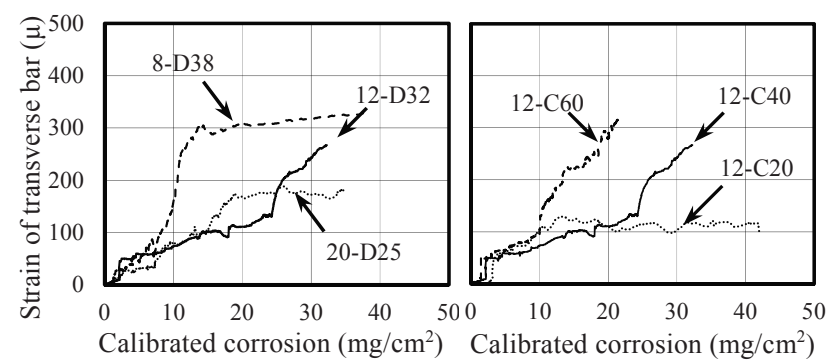

(c) Main bar arrangement $\left(\mathrm{F}_{\mathrm{c}} 48\right)$

(d) Covering depth $\left(\mathrm{F}_{\mathrm{c}} 48\right)$

Fig.9 Comparisons of strain increase in transvers bars induced by corrosion of longitudinal bars 
筋も腐食させた本実験では, その半分程度であった。これは横補強 筋上の腐食ひび割れを通して腐食生成物が大量に流出したことに起 因していると考えられる。

主筋径と本数が異なる試験体を比較した Fig.9(c)から, 主筋径が大 きい $8-\mathrm{D} 38$ 試験体は, $10 \mathrm{mg} / \mathrm{cm}^{2}$ 以下の小さな腐食量から横補強筋ひ ずみが増加している。これは主筋径が大きくなると, 鉄筋腐食によ る膨張圧力が同程度でも, 圧力が作用する円周が長くなり, 大きな リングテンションが生じたことによって, 少ない腐食量でひび割れ を誘発したためと考えられる。しかしながら腐食量が増加すると， 横補強筋ひずみは $300 \mu$ 程度に収束していく傾向が見られ, 腐食生 成物がひび割れ面へ侵入，流出したと推察される。

かぶりの異なる試験体を比較した Fig.9(d)から,かぶりが大きくな ると, コンクリート表面の腐食ひび割れの発生が遅れるが, 横補強 筋のひずみ上昇から主筋周りのコンクリート内部の損傷は大きくな っていると推察され，耐久性の評価に注意が必要である。

\section{4 超音波内部探傷による内部腐食ひび割れ挙動}

\section{1 超音波内部探傷方法}

前節では, 主筋の腐食膨張に起因するひび割れ進展に関して, 横 補強筋を横切る腐食ひび割れ損傷を横補強筋のひずみ上昇から推察 した。コンクリート内部の腐食鉄筋周りのひび割れは放射線状に進 展することを踏まえ, 主筋間の横補強筋に平行な内部腐食ひび割れ 損傷 (Fig. 6) を検討するために, 超音波透過法による内部探傷測定を 行った。測定は腐食実験開始前の健全時に 1 回, 促進腐食開始後ほ
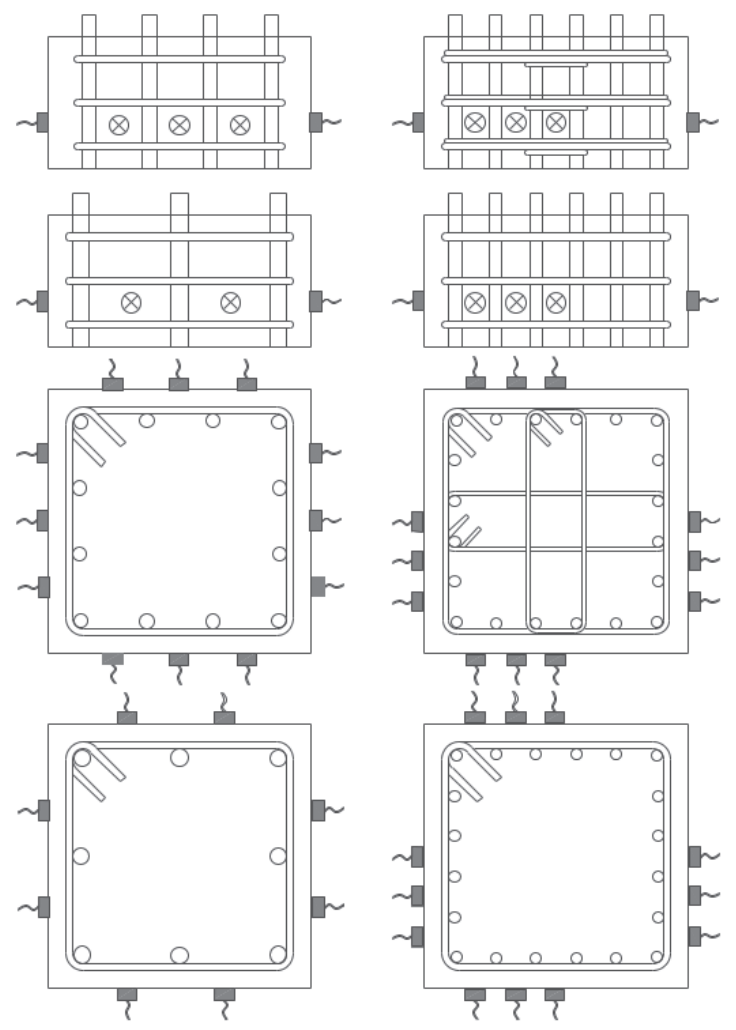

$\sim \otimes$

[ Transmitting and receiving probes

Fig. 10 Measuring points and probes of ultrasonic inspection

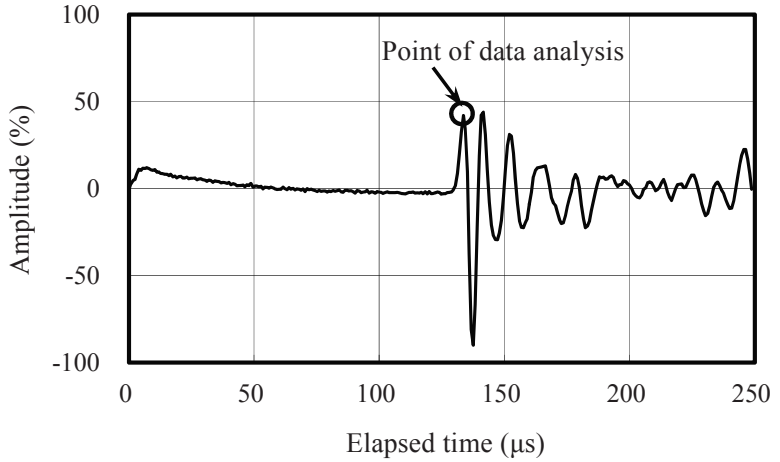

Fig. 11 Point of data analysis for a typical ultrasonic wave

ぼ 1 週間隔で 3 回, その後 3 週間隔で 2 3 回行った。測定点は, Fig. 10 に示寸各試験体の主筋と横補強筋を避けた位置とし，送受信 探触子を接触媒質を介して当てた。探触子は超音波の指向性が鋭い 大径 $(76 \mathrm{~mm}$ ) を使用した。発振器から出力した超音波は試験体内を透 過し，反対側の受信探触子で波形データを採取した。データ解析は Fig. 11 に示寸受信波形の初動波形に着目し，振幅は第 1 波目の正の 信号レベル，音速は第 1 波のピーク点の伝搬時間から求めた。波形 振幅に関しては，腐食量に伴う振幅の挙動を検討寸るため，受信感 度の設定を各試験体・各測定点ごとに固定值とした。

\section{2 腐食量と振幅および音速の関係}

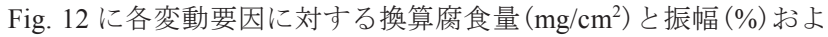
び音速 $\left(\times 10^{3} \mathrm{~m} / \mathrm{s}\right)$ の関係を示す。ここで腐食量は超音波透過挙動に最 も影響を与えると思われる中段と下段の横補強筋 (Fig. 10 参照) の平 均值であり, 振幅と音速は測定点数 (6 または 4) の平均である。腐食 量は，超音波特性が大きく変動する $100 \mathrm{mg} / \mathrm{cm}^{2}$ までを示している。 Fig. 12 (a), (b)に示すように, 全試験体を通して, 腐食量が数 $\mathrm{mg} / \mathrm{cm}^{2}$ 程度の極めて小さな範囲で，振幅，音速共に増加する傾向がある。 この傾向は, セメントペースト内の空隙量が多くなる $\mathrm{F}_{\mathrm{c}} 24$ 試験体に おいて強くなっているため, 腐食生成物が空隙を充填したことに起 因していると思われる。音速に関しては，コンクリート強度すなわ ちセメントペースト内の細孔構造の影響は大きいが，腐食ひび割れ 損傷の進行に伴う音速の減少は大きくはない。一方振幅については, 川越ら ${ }^{16)}$ が内部構造の違いによって大きく変動すると報告している ように，小さな腐食量の範囲で急激に減少している。

川越らはコンクリート内部の欠陥の検出を目的として，超音波透 過法による探傷実験を行っている。柱部材への適用を想定した $800 \times 800 \times 800 \mathrm{~mm}$ のコンクリートブロックの中心部に模擬ジャンカ を埋め込み, 透過超音波の振幅と音速を測定した。その結果, ジャ ンカ部の振幅は健全部よりかなり減少し, 両者の境界部では, 両者 のほぼ平均振幅となった。また, 健全部を伝播した超音波の振幅の 標準偏差 $(=\sigma)$ の 2 倍を減じた值を指標にすることによって模擬ジャ ンカ位置をほぼ検出できることを示した。

本実験でも同様の内部探傷測定により, 内部欠陥 (内部腐食ひび割 れ損傷）と鉄筋腐食量の関係を試験体を透過する超音波の振幅性状 から検討する。振幅は Fig. 6 で示した横補強筋間を連結する内部ひ び割れ損傷の進展とともに小さくなると考えられる。Fig. 12 から全 試験体を通して, 腐食量 $10 \mathrm{mg} / \mathrm{cm}^{2}$ までに振幅が急激に減少してお り, 腐食量が $20 \mathrm{mg} / \mathrm{cm}^{2}$ を超えると, 振幅の低下率は緩やかになっ 
ている。この腐食量は, Table 5 に示した最初に腐食ひび割れがコン クリート表面に現れる腐食量 $\left(14 \mathrm{mg} / \mathrm{cm}^{2}\right.$ から $\left.75 \mathrm{mg} / \mathrm{cm}^{2}\right)$ よりかなり 小さく, コンクリート内部の鉄筋周りの腐食ひび割れは, 早い段階 で発生したと推察できる。

Table 7 に各試験体の健全時の平均超音波振幅 $A_{h}(\%)$ と標準偏差 $\sigma$ (\%)および $A_{h}-2 \sigma$ (\%)を示す。振幅 $A_{h}-2 \sigma$ は Fig. 12 において超音波振 幅の急激な減少途上の振幅, あるいは急激な減少がほぼ終了寸る振 幅に相当する。それ故，Fig. 6 亿示した鉄筋間の内部腐食ひび割れ 損傷を模擬ジャンカと見なすことができれば，川越らが指摘するよ うに, 内部腐食ひび割れの成長過程は $\mathrm{A}_{\mathrm{h}}-2 \sigma$ を指標として検出でき
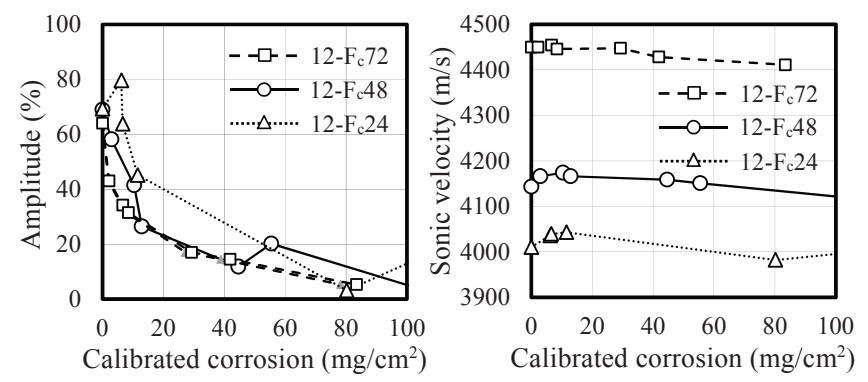

(a) Comparison of different concrete strength (12-bars)
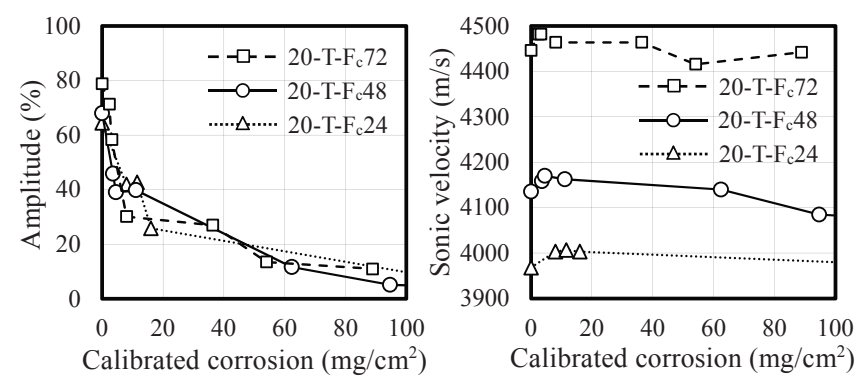

(b) Comparison of different concrete strength (20-bars)
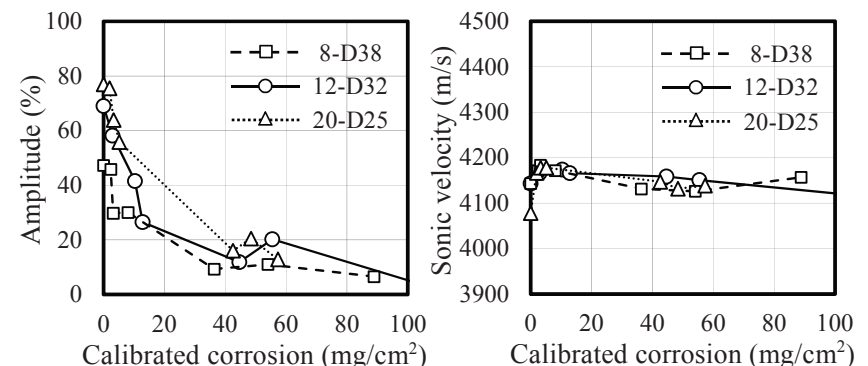

(c) Comparison of different main bar arrangement $\left(\mathrm{F}_{\mathrm{c}} 48\right)$
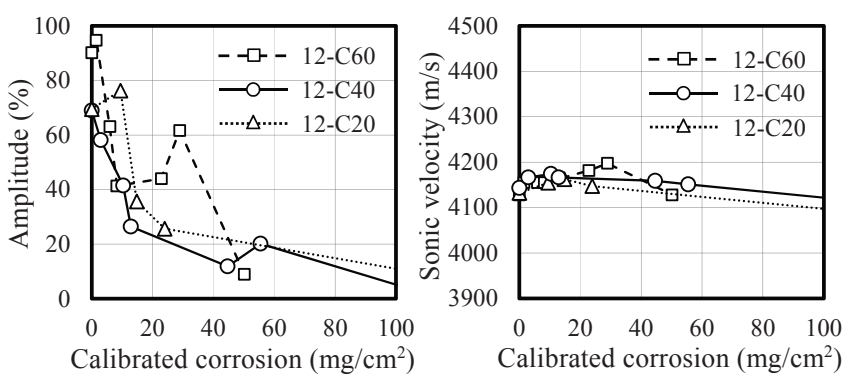

(d) Comparison of different covering depth $\left(\mathrm{F}_{\mathrm{c}} 48\right)$

Fig. 12 Amplitude (left) and sonic velocity (right) behaviors with increasing corrosion rate
Table 7 Amplitude and standard deviation before corrosion test

\begin{tabular}{cccc}
\hline Specimen & $\begin{array}{c}\text { Amplitude } \\
\mathrm{A}_{\mathrm{h}}(\%)\end{array}$ & $\begin{array}{c}\text { Standard } \\
\text { deviation } \sigma(\%)\end{array}$ & $\mathrm{A}_{\mathrm{h}}-2 \sigma(\%)$ \\
\hline $12-\mathrm{F}_{\mathrm{c}} 24$ & 69.3 & 20.5 & 28.4 \\
\hline $12-\mathrm{F}_{\mathrm{c}} 48$ & 69.0 & 13.0 & 43.0 \\
\hline $12-\mathrm{F}_{\mathrm{c}} 72$ & 64.0 & 5.7 & 52.6 \\
\hline $20-\mathrm{T}-\mathrm{F}_{\mathrm{c}} 24$ & 64.6 & 20.4 & 23.8 \\
\hline $20-\mathrm{T}-\mathrm{F}_{\mathrm{c}} 48$ & 68.0 & 13.3 & 41.4 \\
\hline $20-\mathrm{T}-\mathrm{F}_{\mathrm{c}} 72$ & 78.8 & 20.7 & 37.4 \\
\hline $8-\mathrm{F}_{\mathrm{c}} 48$ & 47.3 & 8.1 & 31.1 \\
\hline $20-\mathrm{F}_{\mathrm{c}} 48$ & 77.0 & 24.9 & 27.1 \\
\hline $12-\mathrm{C} 20$ & 69.5 & 11.3 & 46.9 \\
\hline $12-\mathrm{C} 60$ & 90.1 & 10.8 & 68.5 \\
\hline
\end{tabular}

る可能性がある。以上より，超音波透過法は，鉄筋腐食前の RC 部 材の振幅特性が既知の場合, 鉄筋周り腐食ひび割れ損傷領域を検出 する有効な手段であるといえる。また，かぶりの大きい C60 試験体 以外の全試験体は，最終の透過超音波計測時までに腐食生成物が試 験体表面に流出していた。腐食生成物の流出後, コンクリート内部 の流出経路もほぼ確定していると考えられ, 腐食量 $50 \mathrm{mg} / \mathrm{cm}^{2}$ を超 えると, 腐食量の増加に伴う振幅の変動は少なくなっている。ただ し C60 試験体は, 腐食量 $10 \mathrm{mg} / \mathrm{cm}^{2}$ から $30 \mathrm{mg} / \mathrm{cm}^{2}$ の間で振幅が上 昇に転じているが，音速も上昇傾向にあり，さらに腐食生成物が試 験体外に流出していないことを考慮すると, 腐食生成物がかぶりコ ンクリートの空隙に堆積し, 密実になっていることも考えられる。

\section{5. まとめ}

実構造 RC 柱部材および実環境に近い塩害を想定した促進腐食実 験を行い，腐食ひび割れ挙動，横補強筋ひずみ上昇および内部ひび 割れ損傷に及ぼす各種要因の影響について検討した。本実験で得ら れた主な結論を以下に示す。

1）促進腐食による主筋の腐食量に関しては, 塩化物イオンや酸素 が 2 方向から供給される隅角部鉄筋は, 1 方向からのみ供給さ れる中間部鉄筋より積算電流量が多くなり, 厳しい腐食環境に なるため，腐食量が中間部鉄筋の約 2 倍となった。

2) 主筋と横補強筋のかぶり厚の違いによる塩化物イオン濃度の 差異およびマクロセルにより, 横補強筋の実測腐食量はファラ デー則による腐食量より大きく $(1.7$ 倍程度 $)$, 逆に主筋の実測 腐食量は小さく $(0.4$ 倍程度)なった。

3）コンクリート表面に最初に現れる腐食ひび割れは, ブリージン グとコンクリート強度による空隙構造およびかぶりの影響を 受け, 空隙の多い低強度コンクリート $\left(\mathrm{F}_{\mathrm{c}} 24\right)$ は上部横補強筋上, 高強度コンクリート $\left(\mathrm{F}_{\mathrm{c}} 72\right)$ は下部横補強筋上，かぶりが大きく なる(C60) と隅角部主筋上のひび割れが先行した。

4) コンクリート表面の腐食ひび割れ発生時の腐食量に関しては, 塩化物イオン侵入と腐食生成物の流出が容易となる空隙の多 い低強度コンクリート $\left(\mathrm{F}_{\mathrm{c}} 24\right)$ およびかぶりの小さい $(\mathrm{C} 20)$ 試験体 は小さくなった。また, 空隙の少ない高強度コンクリート $\left(\mathrm{F}_{\mathrm{c}} 72\right)$ は腐食生成物が空隙に侵入できず, 集中することによって, 少 ない腐食量でひび割れが表面にまで達した。 
5) 同じ電圧で約 1 か月間, 促進腐食実験を継続した場合, かぶり が厚いほど, またコンクリート強度が高いほど鉄筋腐食に対寸 る抵抗性が高くなった。

6) コンクリート内部の腐食生成物は, 横補強筋間と主筋間に大量 に残留しており, かぶりコンクリートは簡単に外せる状態であ った。一方，コアコンクリート側一の腐食生成物の侵入は見ら れず，鉄筋の腐食性状もかぶり側とコア側で異なっていた。

7）腐食量と共に表面ひび割れは拡幅するが，腐食生成物の試験体 外への流出が始まると, 拡幅が緩やかになった。

8）空隙の多い低強度コンクリートの表面ひび割れの拡幅は, 腐食 生成物が空隙を満たす腐食量 $\left(200 \mathrm{mg} / \mathrm{cm}^{2}\right.$ 程度) まで小さく, コンクリート強度が高くなると, 拡幅速度は大きくなった。

9）かぶりが小さくなると, 腐食生成物の流出が容易になり, 表面 ひび割れ幅の成長は小さくなった。

10）腐食ひび割れ挙動に関しては，コンクリート強度とかぶりの影 響が大きく，配筋による相違は僅かであった。

11）横補強筋のひずみは, ひび割れ幅と同様に, コンクリート強度 が高いほど大きくなる傾向があり, 通常強度鉄筋の $25 \%$ に達し た。また, かぶりが大きい場合, 表面ひび割れが発生する前に, 腐食鉄筋周りの内部損傷によって横補強筋ひずみ上昇は $300 \mu$ に達しており，耐久性の評価に注意が必要である。

12）塩害のように短期間に鉄筋腐食が進行する場合，コアコンクリ 一トの強度特性に及ぼす影響は限定的となり，かぶりコンクリ 一トの剥落, 鉄筋の断面減少による曲げ耐力, 横補強筋のひず み上昇によるせん断耐力が問題になる。

13）超音波内部探傷試験によって, 鉄筋周りの腐食ひび割れ損傷を コンクリート表面の腐食ひび割れ発生より, かなり早い腐食段 階で検出できた。

14）超音波透過法は, 腐食前の平均振幅からの低下性状を検討寸る ことによって, コンクリート内部の損傷状況を推定することが でき，鉄筋腐食前の振幅特性が既知の場合，鉄筋周り腐食ひび 割れ損傷領域を検出する有効な手段である。

本実験より，経年劣化した RC 柱の構造性能に影響を及ぼす鉄筋 腐食ひび割れ挙動（腐食生成物の量とひび割れ幅および性状との関 係等）や横補強筋のひずみ上昇について, 現象論として定性的に検 証できたと考えられる。今後は, コンクリート内部の鉄筋腐食量推 定方法の高精度化ならびに経年劣化 RC 部材の載荷実験・解析を行 い，残存耐力を検証する予定である。

\section{謝辞}

本研究で使用した鉄筋は東京鉄鋼（株）からご提供頂きました。 試験体内部の超音波探傷試験・データ解析は（株）ジャストのご協 力を頂きました。また, 本研究の一部は原子力規制庁の高経年化技 術評価高度化事業ならびに東京工業大学応用セラミックス研究所の 全国共同利用によりました。実験では, 東京都市大学の福井響君, 山本発君の助力を得ました。ここに厚く御礼申し上げます。
解説, 2004.1

2) Youping Liu and Richard E. Weyers : Modeling the Time-to-Corrosion Cracking in Chloride Contaminated Reinforced Concrete Structures, ACI Materials Journal, 95 (6), pp. 675-681, 1998. 12

3) Aris ARYANTO and Yasuji Shinohara : Effect of Confinement and Concrete Strength upon Crack Behaviors Induced by Corrosion-Product Expansion for Reinforced Concrete Members, 日本建築学会構造系論文集, Vol.79,No.696, pp. 305-313, 2014.2

4) Yasuji Shinohara : Effect of Confinement upon Crack Behaviors caused by Corrosion-Product Expansion around Corroding Bars, Proceedings of the 12nd International Conference on Durability of Building Materials and Components, Vol.3 pp. 1577-1584, 2011.4

5) C. Andrade, C. Alonso, and F. J. Molina : Cover cracking as a function of bar corrosion: Part I- Experimental test, Materials and Structures, 26, pp. 453464, 1993

6) 橘高義典, LE PHONG NGUYEN, 塚越雅幸, 松沢幸一 : 鉄筋コンクリー 卜表面のひび割れ発生時の鉄筋腐食量に関する検討, コンクリート工 学年次論文報告集, Vol.33, No1, pp. 1145-1150, 2011.7

7) Kim Vu, Mark G. Stewart, and John Mullard : Corrosion-Induced Cracking: Experimental Data and Predictive Models, ACI Structural Journal, 102 (5), pp. 719-726, 2005.10

8) Dimitri V. Val, Leonid Chernin, and Mark G. Stewart : Experimental and Numerical Investigation of Corrosion-Induced Cover Cracking in Reinforced Concrete Structures, Journal of Structural Engineering, ASCE, 135(4), pp. 376-385, 2009. 4

9) Kukrit Toongoenthong and Koichi Maekaw : Simulation of Coupled Corrosive Product Formation, Migration into Crack and Propagation in Reinforced Concrete Sections, Journal of Advanced Concrete Technology Vol.3, No.2, pp. 253-265, 2005.6

10) 土木学会 : コンクリート標準示方書, 維持管理編, 2007.3

11) 土木研究所 : 塩害環境下にあるコンクリート中鉄筋のマクロセル腐食 形成機構, 土木研究所資料, 土木研究所編, pp. 38, 2009.1

12）松林裕二, 桝田佳宽, 笹渕優樹 : 塩化物を含んだコンクリート中の鉄筋 腐食速度に関する屋外暴露実験 日本建築学会構造系論文集, No.536, pp. 9-15, 2000.10

13）土木学会 : 鉄筋腐食・防食および補修に関する研究の現状と今後の動向 (その 2 )，コンクリート技術シリーズ 40,pp. 185-193, 2000.12

14）田中享二, 胡桃澤清文 : セメント硬化体の細孔観察手法の開発，日本建 築学会構造系論文集, No.532, pp. 21-26, 2009.6

15) 篠原保二, 林靜雄: 鉄筋コンクリート柱の損傷過程におけるせん断伝達 メカニズムに及ぼす軸力の影響, 日本建築学会構造系論文集, No.639, pp. 897-905, 2009.5

16) 川越洋樹, 柳瀬高仁, 池ヶ谷靖, 村田光, 柳沢学: 超音波透過法による ジャンカ検出の実験, 日本建築学会大会学術講演梗概集, A-1, 材料施 工, pp. $1255-1256,2009.8$

Appendix table 1 Conversion factor for mass loss

\begin{tabular}{c|c}
\hline Reinforcement & Conversion factor from $\mathrm{mg} / \mathrm{cm}^{2}$ to $\%$ \\
\hline D13 & 0.0402 \\
\hline D16 & 0.0321 \\
\hline D25 & 0.0201 \\
\hline D32 & 0.0160 \\
\hline D38 & 0.0134 \\
\hline
\end{tabular}

\section{参考文献}

1）日本建築学会 : 鉄筋コンクリート造建物の耐震性能評価指針（案）・同 


\title{
CRACKING BEHAVIOR CAUSED BY CORROSION AND INCREASING STRAIN OF TRANSVERSE BARS IN RC COLUMNS UNDER A SALT-ATTACK ENVIRONMENT
}

\author{
Yasuji SHINOHARA* , Yuichiro GAKUHARI **, Hiroki MARUYAMA***, \\ Jeongsoo NAM $^{* * * *}$ and Hiroyuki MIYAUCHI***** \\ * Assoc. Prof., Struct. Eng. Research Center, Tokyo Institute of Technology, Dr.Eng. \\ ** Nuclear Power Department, Kajima corporation, Master of Engineering \\ *** Grad. Stud., Dept. of Environmental Sci. and Tech., Tokyo Institute of Technology \\ **** Researcher, Structural Engineering Research Center, Tokyo Institute of Technology, Dr.Eng. \\ ***** Senior Research Engineer, Department of Building Materials and Components, BRI, Dr.Eng.
}

Corrosion of reinforcing bar is an important problem on the deterioration of Reinforced Concrete (RC) structures because it may induce cracking and falling of concrete cover as well as degrading reinforcement capacity. There have been a large number of experimental studies to evaluate the cracking behaviors of concrete under corrosion of reinforcement for past years. However, most of their specimens have single bar installed in concrete prism or cylinder without any transverse bar.

To get closer to a real condition of corrosive environment, this research tried to reproduce an actual bar arrangement and a penetration of chloride ions. The present study is intended to obtain a general tendency on crack propagation, crack width and strain behavior of transverse bar. The main purpose is to estimate the corrosion level of reinforcement in the concrete from crack width which can be easily measured.

Ten specimens which were assumed to be elements cut from RC columns were designed and produced. They have a large cross section of $600 \times 600 \mathrm{~mm}$, a cutoff height of $300 \mathrm{~mm}$. The top and the bottom of the column specimens were coated by epoxy resin to avoid penetration of $\mathrm{NaCl}$ solution. The variable factors of specimens are concrete strength $\left(\mathrm{F}_{\mathrm{c}} 24, \mathrm{~F}_{\mathrm{c}} 48, \mathrm{~F}_{\mathrm{c}} 72\right)$, longitudinal bar arrangement (20-D25, 12-D32, 8-D38), transverse bar arrangement (D16@100, D13+D10@100) and cover depth (20,40,60 mm).

The specimens were cured for 28 days before accelerated corrosion test was applied. During the accelerated corrosion test, the specimens were placed in the tank containing $3 \%$ of $\mathrm{NaCl}$ solution. A direct-constant voltage was basically given, but by switching off the longitudinal bars, different amount of current was introduced into longitudinal and transverse bars in response to their diffusion progress of chloride ions depending on their cover depth. The cracks on the surface of cover were visually observed and the crack width at certain locations was frequently measured to monitor the crack width increments. In addition to the corrosion-crack width on the surface, the internal cracking was detected by an ultrasonic inspection during corrosion test.

A corrosion cracking was appeared first on the surface over transverse bars at top and bottom of specimens and over longitudinal bar at corner of specimens. The appearance of corrosion cracking in high strength concrete specimens $\left(\mathrm{F}_{\mathrm{c}} 72\right)$ was later than other specimens. However, comparing among $\mathrm{F}_{\mathrm{c}} 24, \mathrm{~F}_{\mathrm{c}} 48$, and $\mathrm{F}_{\mathrm{c}} 72$ at a same corrosion amount, $\mathrm{F}_{\mathrm{c}} 72$ showed the larger growth of crack width and larger strain in transverse bars because corrosion production localized into a crack due to the lower porosity in higher concrete strength.

After accelerated corrosion tests, cover concrete was removed to observe the internal cracking. Corrosion products were observed between cover concrete and transverse bars, especially, along with vertical layer throughout the three transverse bars. All reinforcing bars were taken out of concrete columns and soaked into $10 \%$ diammonium hydrogen citrate solution. After chemically and mechanically cleaning, the weight loss of corroded rebars was measured. The measured mass loss of transverse bar was larger than that of longitudinal bars because of its small cover thickness. As for the mass loss of longitudinal bars, a corner bar was more corroded than an intermediate bar because chloride ions can be penetrated from two directions. The ratio for average weight loss of transverse bars, corner, and intermediate longitudinal bars was about 9:4:2.

An amplitude by ultrasonic inspection was sharply reduced with increasing in corrosion rate at very small corrosion, and it showed a possibility to detect inner crack behaviors between reinforcing bars using an amplitude deducted by twice standard deviation for an uncorroded specimen. 